\title{
ilkokul Öğrencilerinin Sözel Problem Çözme Performansı Üzerinde Anlamsal Tutarlılık Etkisi
}

\author{
Hicran Nurse YILDIZ* \\ Derya $\mathrm{CAN}^{* *}$
}

Öz: Sözel problemlerde karmaşıklık yaratan durumlardan birisi problemlerdeki anahtar sözcüklerin problemin çözümü için gerekli işlemle tutarlı olup olmadığıdır. Bu araştırmada, ilkokul öğrencilerinin işlemle tutarlı ve tutarsız anahtar sözcükler içeren sözel problemlerdeki performanslarının Türkçe ve matematik dersi akademik başarılarına göre nasıl değiştiğinin ve problem çözme performansı üzerinde anahtar sözcüklerin rolünün incelenmesi amaçlanmıştır. Araştırmanın nicel aşamasına, uygun örnekleme yöntemiyle belirlenen ve ilkokul 3. ve 4. sınıfta öğrenim görmekte olan 100 öğrenci katılmıştır. Araştırmanın nitel aşamasında yarı yapılandırılmış görüşmeler yapılmış olup katılımcılar maksimum çeşitlilik örneklemesi yoluyla belirlenmiştir. Araştırma sonucunda, işlemle tutarlı anahtar sözcükler içeren problemlerde öğrenciler daha yüksek performans gösterirken, işlemle tutarsız anahtar sözcükler içeren sözel problemlerde daha düşük performans göstermiştir. Öğrencilere işlem seçimlerinin gerekçeleri sorulduğunda, büyük bir çoğunluğu işlemle tutarlı ve tutarsız anahtar sözcüklere vurgu yapmıştır. İşlemle tutarsız anahtar sözcüklerin yer aldığı problemler, genellikle düşük ve orta başarı grubundaki öğrencilerin hatalı işlem tercihinde bulunmasına neden olmuştur. Özellikle ilkokul döneminde öğrencilerin okuduğunu anlama becerilerinin geliştirilmesi ve sözel problemlerin anlamsal-dilsel özellikleri ile nasıl başa çıkılacağının öğretilmesi öğrencilerin ilerleyen yaşlardaki performanslarının olumlu yönde gelişmesini destekleyebilir.

Anahtar Sözcükler: Sözel Problem, Problem Çözme, Anlamsal Tutarllık, İlkokul Öğrencileri

\section{Lexical Consistency Effect on Primary School Students' Problem-Solving Performance}

\begin{abstract}
One of the situations that creates complexity in word problems is whether or not the keywords in the problems are consistent with the mathematical operations required for the solution of the problem. In this study, the aim is to examine the problem-solving performance of students with regard to word problems that contain keywords that are consistent and inconsistent with the necessary mathematical operations. The participants in the quantitative part of the study are 100 students in the third and fourth grades of primary schools who were selected through convenience sampling. In the qualitative phase of the research, semi-structured interviews were conducted, and the participants were selected through maximum variation sampling. It was found that the student performance is much higher in the case of word problems with lexically-consistent keywords, whereas their performance is much lower in the case of word problems with lexically-inconsistent keywords. When the participants were asked to justify their choice, the majority stated that they considered the keywords which were consistent and which were inconsistent with the mathematical operations. Problems with keywords that are inconsistent with such operations generally caused students in the lower and medium achievement group to choose incorrect operations to solve the problems. Developing students' reading comprehension skills and teaching them how to deal with the semantic-linguistic features of word problems, especially in the primary school period, may positively support their performance when they are older.
\end{abstract}

Keywords: Word Problems, Problem Solving, Lexical Consistency, Primary School Children

*Burdur Mehmet Akif Ersoy Üniversitesi, Eğitim Fakültesi, Temel Eğitim Bölümü, Burdur, Türkiye, e-posta: hicrannurse@gmail.com, ORCID: https://orcid.org/0000-0002-2116-689X

***Brdur Mehmet Akif Ersoy Üniversitesi, Eğitim Fakültesi, Temel Eğitim Bölümü, Burdur, Türkiye, e-posta: deryacakmak@mehmetakif.edu.tr, ORCID: https://orcid.org/0000-0003-1257-8793 
Matematik eğitiminde önemli bir yere sahip olan problem çözme, öğretim programlarının önemli bir parçasını oluşturmaktadır (Van de Walle, 1994). Öğrencilerin problem çözme sürecinde problemi anlamaları, çözüm stratejisini belirlemeleri ve problemi çözmeleri beklenmektedir (Baki, 2006; Olkun ve Toluk-Uçar, 2007). İlkokul öğrencilerinin sözel problem çözme becerisini inceleyen çalışmalara bakıldığında, öğrencilerin yaptıkları hataların incelendiği ve birtakım yetersizliklerinin tespit edildiği görülmektedir (İskenderoğlu, Akbaba-Altun ve Olkun, 2004). Sözel problem, sayısal veriler ve işlemler kullanılarak bir ya da daha fazla matematik sorusuna yanıt aranan problem durumlarının sözel tanımlamalarını içermektedir (Verschaffel, Greer ve De Corte, 2000). Yapılan araştırmalara göre hem dilsel hem de sayısal karmaşıklık, sözel problemlerin çözümünde birtakım zorluklara yol açmaktadır (Daroczy, Wolska, Meurers ve Nuerk, 2015). İşleyen bellek, okuduğunu anlama, aritmetik hesaplama gibi farklı beceri ve işlevler sözel problem çözme becerisi üzerinde etkilidir (De Corte, Verschaffel ve Pauwels, 1990). Sözel problem çözme becerisi üzerinde etkisi tespit edilen etmenlerden birisi de tutarlılık etkisidir (Verschaffel, De Corte ve Pauwels, 1992). Tutarlılık etkisi, matematiksel sözel problemlerde problem çözümü için gerekli işlemle tutarlı olmayan anahtar sözcüklerin problem ifadesinde yer alması durumunda, problem çözücülerin hata yapma ihtimalinin artması olarak ifade edilmektedir (Boonen, de Koning, Jolles, ve van der Schoot, 2016; de Koning ve van der Schoot, 2020; Verschaffel ve diğerleri, 1992). Sözel problemlerde tutarlılık etkisine sebep olan en önemli faktör, problem ifadesinde işlemle tutarlı ya da işlemle tutarsız anahtar sözcüklerin bulunmasıdır. Örneğin, toplama işlemi yapmayı gerektiren bir sözel problem ifadesinde "daha az, eksik, eksilmek" gibi çıkarma işlemini çağrıştıran anahtar sözcüklerin yer alması o sözel problemin işlemle tutarsız anahtar sözcükler içerdiğini göstermektedir (Hegarty, Mayer ve Green, 1992). Toplama işlemi yapmayı gerektiren sözel problem ifadesinde "fazla, artmak, eklemek" gibi toplama işlemini çağrıştıran anahtar sözcüklerin yer alması ise o sözel problemin işlemle tutarlı anahtar sözcükler içerdiğini göstermektedir (Hegarty ve diğerleri, 1992). Bu durumda tutarlılık, problem çözümü için gerekli işlemle tutarlı anahtar sözcüklerin varlığına işaret ederken, tutarsızlık işlemle tutarsız anahtar sözcüklerin varlığına işaret etmektedir (Boonen, van der Schoot, Van Wesel, De Vries, ve Jolles, 2013).

Farklı yaş gruplarındaki bireylerin problem çözme performansı üzerinde tutarlılık etkisini inceleyen araştırmalar yapılmıştır (Boonen ve diğerleri, 2013; Hegarty ve diğerleri, 1992; van der Schoot, Bakker Arkema, Horsley, van Lieshout, 2009). Bu araştırmalar başarısız problem çözücülerin sözel problemlerde yer alan tutarsız anahtar sözcüklerden etkilendiğini ve problem çözümlerinde yanlış işlem tercihinde bulunduklarını ortaya koymuştur. Ayrıca araştırmalara katılan bireylerin problem çözme için harcadıkları süre, problemlerdeki sayılara ve anahtar sözcüklere odaklanma süreleri tespit edilmiş ve bu değişkenler ile tutarsız anahtar sözcükler içeren problemleri çözme performansları arasındaki ilişki tanımlanmıştır (Hegarty ve diğerleri 1992). Başka bir çalışmada, öğrencilerin okuduğunu anlama becerileri ile tutarlı ve tutarsız yapıdaki problemleri çözme performansları arasındaki ilişki ortaya konulmuştur (Boonen ve diğerleri, 2016). Yapılan araştırmalar sözel problem çözme becerisi üzerinde aritmetik işlem becerilerinin ve dilsel faktörlerin etkisini ortaya koymuş olup özellikle tutarsız ifadeler içeren problemlerde dilsel faktörlerin etkisi tespit edilmiştir (Boonen ve diğerleri, 2013; Hegarty ve diğerleri, 1992; van der Schoot, Bakker Arkema, Horsley ve van Lieshout, 2009).

Sözel problemlerde başarıya ulaşmada önemli olan bir diğer etmen ise okuduğunu anlama becerisidir. İyi sözel problem çözücüler, matematiksel problem çözmeye ilişkin bilgilerini, kavramsal anlayışlarını ve problem durumunda yer alan sözel bilgiyi doğru sonuca ulaşabilmek için başarılı şekilde kullanabilirler (Thevenot, Devidal, Barrouillet ve Fayol, 2007). Bu durum sözel problem çözmenin aynı zamanda okuduğunu anlamayı içeren bilişsel bir süreci de gerektirdiğinin bir göstergesidir (Fuchs, Fuchs, Compton, Hamlett ve Wang, 2015). Tutarsız anahtar sözcük içeren sözel problemlerde sorun yaşayan problem çözücüler, sözel problem metnini yüzeysel bir şekilde okumakta, tam ve doğru bir şekilde gerçek problem ifadesini temsil eden çözüme ulaşamamaktadır (de Koning ve van der Schoot, 2020). Türkçe Dersi Öğretim Programı (2019) öğrencilerin okuduklarını anlayarak eleştirel bir bakış açısıyla değerlendirmelerini sağlamayı amaçlamakta ve öğrencilerin Türkçe dersinde edindikleri kazanımlar, okuduğunu anlama becerisini kazandırmada önemli bir rol oynamaktadır (Milli Eğitim Bakanlığı [MEB], 2019). Okuduğunu anlama becerisinin gelişimi ise anlam kurmaya yönelik okumayı desteklemekte ve bu durum öğrencinin 
problem çözme becerisini olumlu şekilde etkileyebilmektedir (Albayrak ve Erkal, 2003). Yapılan araştırmalarda, aynı yolla çözülecek sorunun aritmetik işlem ve sözel problem formlarında, bazı öğrencilerin aritmetik işlem sorularını yapabilirken sözel problemleri yapamadığı saptanmış (Kroll ve Miller, 1993) ve öğrencilerin problem çözme becerisinin aritmetik işlem becerisiyle birlikte problemi anlama becerisinden de etkilendiği tespit edilmiştir (Tertemiz, 1994). Araştırma sonuçlarına göre, hem aritmetik işlem becerisi hem de okuduğunu anlama becerisi sözel problem becerisiyle yakından ilişkili olan iki beceriyi yansıtmaktadır (Andersson, 2007; Fuchs ve diğerleri, 2006). İlkokul Türkçe Dersi Öğretim Programı'nın (2019) amaçları göz önünde bulundurulduğunda, okuduğunu anlama ve çıkarımda bulunma becerileri, İlkokul Matematik Dersi Öğretim Programı'nın (2018) amaçları göz önünde bulundurulduğunda ise problem çözme becerisi önemli yer tutmaktadır. Bu doğrultuda, Türkçe ve matematik derslerinde elde edilen akademik başarının okuduğunu anlama, çıkarımda bulunma ve problem çözme becerilerini yansıtması beklenmektedir. Bu araştırmada, ilkokul 3. ve 4. sınıfta öğrenim görmekte olan öğrencilerin işlemle tutarlı ve tutarsız anahtar sözcükler içeren sözel problemlerdeki performanslarının Türkçe ve matematik dersi akademik başarılarına göre nasıl değiştiğinin ve problem çözme performansı üzerinde anahtar sözcüklerin rolünün incelenmesi amaçlanmiştır.

\section{Tutarlılık Etkisi}

Sözel problemlerde karmaşıklık yaratan durumlardan birisi problemlerdeki anahtar sözcüklerin problemin çözümü için gerekli işlemle tutarlı olup olmadığıdır (Hegarty ve diğerleri, 1992; Hegarty, Mayer ve Monk, 1995; Pape, 2003). İşlemle tutarlı anahtar sözcükler içeren bir sözel problemde, ilgili ifade (örneğin, "daha fazla") aritmetik işlemle (toplama) ilişkilidir. Ancak sözel problemin tutarsız ifade içeren örneğinde, ilgili ifade (örneğin, "daha az") aritmetik işlemle (toplama) ilişkili değildir. Örneğin, "Bakkalda, bir şişe süt 7 liradır. Markette ise bir şişe süt bakkaldaki sütün fiyatından 2 lira daha fazladır. Markette süt kaç liradır?" sorusu işlemle tutarlı anahtar sözcük içeren bir sözel problem örneğidir. Bu problem toplama işlemi yapmayı gerektirmekte ve anahtar sözcük olarak "daha fazla" ifadesi yer almaktadır (Boonen ve diğerleri, 2013). "Bakkalda, bir şişe süt 7 liradır. Yani marketteki bir şişe sütün fiyatına göre 2 lira daha fazladır. Markette süt kaç liradır?" sorusu işlemle tutarsız anahtar sözcük içeren bir sözel problem örneğidir. Çünkü bu soru "daha fazla" ifadesi yer almasına rağmen çıkarma işlemi yapmayı gerektirmektedir (Boonen ve diğerleri, 2013). Bazı sözel problemler "daha az" ya da "daha çok" gibi belirteçler içermektedir. Çocuklar sözel problemleri çözerken "daha az" kavramını çıkarma, "daha çok" kavramını ise toplama işlemi ile ilişkilendirebilmektedir (Hegarty ve diğerleri, 1995). Başarılı problem çözücüler daha çok problemdeki değişkenlere ve o değişkenle ilgili kavramlara odaklanmakta ve problemi tekrar tekrar okumaktadırlar (Pape, 2003). Başarısız problem çözücüler ise daha çok sayılara ve sayılarla ilişkili kavramlara odaklanarak dilsel işaretlere göre sözel ifadeyi işleme aktarmaktadır (Hegarty ve diğerleri, 1992). Bu durum, "daha çok" kavramının çıkarmayla, "daha az" kavramının toplamayla ilişkili olduğu anlamsal tutarsızlık içeren problemlerde öğrencilerin yanlış çözümler yapmalarına sebep olmaktadır. Örneğin, Hegarty ve diğerleri (1995) yaptıkları çalışmada, işlemle tutarlı ve tutarsız ifadeler içeren problemlerde, başarısız problem çözücülerin çözümlerini sayılara ve anahtar kelimelere odaklanarak yapacakları, başarılı problem çözücülerin ise problemde tanımlanan duruma ilişkin bir model ortaya koyacakları ve bu modele göre çözümlerini planlayacakları hipotezi ile araştırmaya başlamışlardır. Araştırma sonucunda, başarısız problem çözücülerin tutarsız problemlerde tutarlı problemlere göre daha çok hata yaptıkları görülmüştür. Ayrıca çalışmada problem çözücülerin problemdeki sayıya ve anahtar sözcüğe bakma süreleri kayıt altına alınmıştır. Araştırma sonucunda başarısız problem çözücülerin sayılara ve anahtar sözcüklere odaklanma süresi diğerlerinden daha yüksek bulunmuştur. Sonuç olarak başarısız problem çözücüler tutarsız ifadeler içeren problemi çözmek için daha çok zaman harcarken bu süreçte problemdeki diğer bilgilendirici ifadeleri incelemek yerine daha çok sayılara ve anahtar sözcüklere odaklanmışlardır (Hegarty ve diğerleri, 1995). İskenderoğlu ve diğerleri (2004) tarafından yapılan çalışmada, ilkokul öğrencilerinin anahtar sözcük içeren ve içermeyen standart sözel problemlerdeki işlem seçimleri incelenmiştir. Araştırma sonucunda, öğrencilerin hangi anahtar sözcüklerde hangi işlemleri kullanacaklarını ezberleme yoluna gittikleri için bazen yanlış çözümler yaptıkları görülmüştür. Örneğin, bazı öğrenciler için "verince" sözcüğü çıkarmayı, "fazla" sözcüğü ise toplamayı çağrıştırmıştır. Bu durumun nedeni sınıfta "fazla, artmak, eklemek" gibi 
sözcüklerin geçtiği problemlerde genellikle toplama, "azalmak, eksilmek, çıkmak" gibi sözcüklerin geçtiği problemlerde ise genellikle çıkarma işleminin yapılması ile açıklanmıştır. Soylu (2007) tarafından yapılan araştırmada ortaokul öğrencilerinin sözel problemleri çözerken sergilemiş oldukları yaklaşımlar incelenmiştir. Araştırma sonucunda, işlem seçiminde hata yapan öğrencilerin problemin anlamından daha çok anahtar sözcükleri dikkate aldıkları görülmüştür. Çelik ve Taşkın (2015) tarafından yapılan çalışmada, işlemle tutarlı ve tutarsız anahtar sözcük içeren problemlerin ortaokul öğrencilerinin problem çözme sürecini nasıl etkilediği incelemiştir. Araştırma sonucunda öğrencilerin tutarlı dil kullanılarak oluşturulmuş sözel problemleri çözmede tutarsız dil kullanılarak ifade edilen problemlere oranla daha başarılı oldukları sonucuna ulaşılmıştır.

\section{Araştırmanın Amacı ve Önemi}

$\mathrm{Bu}$ araştırmada, ilkokul 3. ve 4. sınıf öğrencilerinin işlemle tutarlı ve tutarsız anahtar sözcükler içeren sözel problemlerdeki performanslarının, Türkçe ve matematik dersi akademik başarılarına göre nasıl farklılaştığının incelenmesi amaçlanmıştır. Ayrıca öğrencilerin problem çözme performansında, işlemle tutarlı ve tutarsız anahtar sözcüklerin rolünün betimlenmesi hedeflenmiştir. İlkokul Matematik Dersi Öğretim Programı'nda (2018) sözel problemlerin önemli bir yeri bulunmaktadır. Dolayısıyla öğrencilerin matematik dersi başarısında problem çözme becerileri önemli bir yere sahiptir. Öğrencilerin Türkçe dersi başarıları ise okuduğunu anlama ve dil becerilerine ilişkin gelişimleri açısından bilgi sağlamaktadır. Bu sebeple bu iki derse ilişkin akademik başarı düzeyine bağlı olarak sözel problem çözme becerisinde anlamsal tutarlılık etkisinin incelenmesi amaçlanmıştır. Ayrıca öğrencilerin problem çözme performansında anahtar sözcüklerin rolünün araştırılması tutarsız anahtar sözcükler içeren problemlerde beklenen performans düşüklüğünün anahtar sözcüklerden kaynaklanıp kaynaklanmadığının belirlenebilmesi açısından önemlidir.

Yapılan araştırmalarda, sözel problemlerde anlamsal açıdan tutarlı ve tutarsız anahtar sözcüklerin yer almasının öğrencilerin problem çözme becerisine etkisi ortaya konulmuştur (Boonen ve diğerleri, 2013; Hegarty ve diğerleri, 1995). Yapılan incelemeler sonucunda, özellikle başarısız problem çözücülerin sözel problemi çözerken daha çok sayılara ve anahtar sözcüklere odaklandıkları tespit edilmiştir (Hegarty ve diğerleri, 1995). Başarılı problem çözücüler ise problemdeki değişkene, o değişkenle ilgili kavramlara odaklanmakta ve problemde tanımlanan duruma ilişkin model ortaya koymaya çalışmaktadır (Hegarty ve diğerleri, 1995; Pape, 2003). Ulusal alanyazında yapılan araştırma sonuçlarına göre, öğrencilerin problemi anlamaktan daha çok anahtar sözcüklere odaklandıkları, özellikle tutarsız dil kullanılarak oluşturulan sözel problemlerde öğrencilerin daha başarısız oldukları tespit edilmiştir (Çelik ve Taşkın, 2015; İskenderoğlu ve diğerleri, 2004; Soylu, 2007). İşlemle tutarsız anahtar sözcükler içeren sözel problemlerin çözümünde öğrencilerin zorlandıklarına ilişkin araştırma sonuçları, bu sorunun yaklaşık 15-20 yıldır devam ettiğini göstermektedir. Bu süreç içerisinde, 2005 yılından itibaren yapılandırmacı yaklaşımın benimsendiği anlayışla öğretim programları güncellenmiştir. Birtakım değişikliklerle günümüzde uygulanmaya devam eden matematik ve Türkçe dersleri öğretim programlarında hem problem çözme becerisi hem de okuduğunu anlama becerisi önemli bir yer tutmaktadır (MEB, 2018; 2019). Dolayısıyla öğrencilerin bu derslerde sağladıkları akademik başarı ile öğrencilerin problem ifadesini anlamayı, çıkarımda bulunmayı gerektiren, tutarlı ve tutarsız anahtar sözcükler içeren sözel problemlerde gösterdiği başarı arasında nasıl bir ilişki olduğu merak konusudur. Bu gerekçelerden yola çıkılarak, ilkokul 3. ve 4. sınıf öğrencilerinin işlemle tutarlı ve tutarsız anahtar sözcükler içeren sözel problemlerde problem çözme performansının incelenmesi, performanslarının Türkçe ve matematik dersi akademik başarı durumlarına göre nasıl değiştiğinin araştırılması ve bu süreçte anahtar sözcüklerin rolünün betimlenmesi amaçlanmıştır. Bu kapsamda "İlkokul 3. ve 4. sınıf öğrencilerinin işlemle tutarlı ve tutarsız anahtar sözcükler içeren sözel problemlerde performansları nasıldır?" sorusuna yanıt aranacak olup alt araştırma soruları şunlardır:

1. İlkokul 3. ve 4. sınıf öğrencilerinin işlemle tutarlı ve tutarsız anahtar sözcükler içeren sözel problemlerdeki performansları arasında anlamlı bir farklılaşma görülmekte midir? 
2. İlkokul 3. ve 4. sınıf öğrencilerinin işlemle tutarlı ve tutarsız anahtar sözcükler içeren sözel problemlerdeki performansları, matematik ve Türkçe dersi akademik başarı gruplarına göre anlamlı şekilde farklılaşmakta mıdır?

3. Farklı düzeylerde akademik başarıya sahip öğrenciler, işlemle tutarlı ve tutarsız ifadeler içeren sözel problemleri çözme sürecinde anahtar sözcüklerden nasıl yararlanmaktadırlar?

\section{Yöntem}

Sözel problemlerin anlamsal açıdan işlemle tutarlı ve tutarsız anahtar sözcükler içeren türlerinde öğrencilerin performanslarının Türkçe ve matematik dersi akademik başarılarına göre nasıl değiştiğini ve performanslar üzerinde anahtar sözcüklerin rolünü incelemeyi amaçlayan bu araştırmada, var olan durum ortaya koyulmaya çalışıldığından betimsel araştırma türlerinden tarama deseni kullanılmıştır. Araştırma kapsamında çalışmanın öncelikle nicel aşaması yürütülmüştür. Bu aşamada öğrencilerin işlemle tutarlı ve işlemle tutarsız anahtar sözcük içeren sözel problemlerdeki performanslarının Türkçe ve matematik dersi akademik başarılarına göre nasıl farklılaştığı incelenmiştir. Araştırmanın nicel aşaması tamamlandıktan sonra, nitel aşamaya geçilmiş ve akademik başarı düzeyi düşük, orta ve yüksek olan öğrencilerin her iki problem türündeki performansları, işlem seçimlerine ve işlem seçimlerinde anahtar sözcüklerin rolüne bağlı olarak incelenmiştir. Tarama modellerinden örnek olay tarama modeline göre gerçekleştirilen bu süreç genel taramalar ile elde edilen verilerin derinlemesine incelenmesine olanak sağlamıştır. Örnek olay tarama modeli, genel taramalar hakkında daha ayrıntılı bilgi edinme, nedenler ve nasıllar hakkında nitel veri toplama ve yorumlama şansı sunmaktadır (Karasar, 2017).

\section{Katılımcilar}

Araştırmanın nicel aşamasına, uygun örnekleme yöntemiyle belirlenen ve ilkokul 3. ve 4. sınıfta öğrenim görmekte olan 100 öğrenci katılmıştır. Öğrencilerin \%49'u kız, \%51'i erkek olup \%47'si 3. sınıfta, \%53'ü 4. sınıfta öğrenim görmektedir. Araştırmaya aynı okulda öğrenim görmekte olan, ikisi üçüncü sınıf, ikisi dördüncü sınıf olmak üzere dört farklı şubeden öğrenciler katılmıştır. Öğrencilerin öğrenim gördüğü okul Burdur il merkezinde sosyoekonomik açıdan orta düzey bir bölgede bulunmaktadır. Öğrencilerin yaşları 910 aralığında değişmektedir. Öğrenciler dört yıllık ilkokul dönemine yönelik öğretim süreci sonrasında ortaokula geçmektedir. Öğrencilerin ilkokul döneminin sonunda Türkçe ve matematik derslerinde edinmesi beklenen beceriler öğretim programları kapsamında belirlenmiştir (MEB, 2018; 2019). Öğrencilerin bu hedeflenen becerileri edinmeden mezun olmaları, akranlarıla aralarındaki farkın ilerleyen yıllarda daha da açılmasına yol açmaktadır (Spencer, Fuchs ve Fuchs, 2020). Bu sebeple ilkokul 3. ve 4. sınıf öğrencileri çalışmaya dâhil edilmiş ve çalışmanın amacı doğrultusunda öğrencilerin performansları incelenmiştir. Araştırmanın nitel aşamasında yarı yapılandırılmış görüşmeler yapılmış olup katılımcılar maksimum çeşitlilik örneklemesi yoluyla belirlenmiştir. Bu amaçla, Türkçe ve matematik derslerine ait akademik başarı gruplarını oluşturmak için öğretmenlerden elde edilen verilere göre sıralama gerçekleştirilmiş ve her iki ders için alt ve üst \%27'lik grupta yer alan öğrenci grupları belirlenmiştir (Kelley, 1939). Kalan öğrenciler ise akademik başarı açısından orta düzeyde yer alan öğrenci grubunu oluşturmuştur. Matematik dersi akademik başarısı ve Türkçe dersi akademik başarısı değişkenlerinin her ikisinde de alt ve üst \%27'lik grupta yer alan öğrenciler ile orta düzeyde yer alan öğrenciler arasından seçim yapılmıştır. Ayrıca sınıf düzeyi de göz önünde bulundurulmuş olup 10'u 3. sınıfta, 10'u 4. sinıfta öğrenim görmekte olan toplam 20 öğrenci ile görüşmeler gerçekleştirilmiştir. Öğrencilere kod isimler verilmiş olup Ö1-Ö9 arasındaki öğrenciler düşük başarı grubunda, Ö10-Ö15 arasındaki öğrenciler orta başarı grubunda, Ö16-Ö20 arasındaki öğrenciler ise yüksek başarı grubundadır. Her bir başarı grubunda yer alan öğrencilerin yarı yapılandırılmış görüşmeye katılımı için seçim rastgele gerçekleştirilmiştir.

\section{Veri Toplama Araci}

Veri toplama aracı olarak İskenderoğlu ve diğerleri (2004) tarafından yapılan çalışmada kullanılan sözel problemlerden yararlanılmıştır. Ancak bazı problemlerin bağlamında birtakım değişiklikler yapılmıştır. Örneğin, o dönemde öğrenciler tarafından bilinen "taso" kavramının katılımcı gruba yabancı bir kavram 
olabileceği durumu göz önünde bulundurularak "oyun kartı" düzenlemesi yapılmıştır. Veri toplamanın aracının 2004 yılında gerçekleştirilen bir çalışmadan (İskenderoğlu ve diğerleri, 2004) uyarlanmış olması akla 2005 yılında gerçekleştirilen ve yapılandırmacı yaklaşımın benimsendiği paradigma değişikliğini getirse de kullanılan sözel problemler, öğrencilerin temel problem çözme performansını belirleyebilmek, problemi anlama, problem de kullanılan anahtar sözcüklere odaklanma ya da odaklanmama durumlarını tespit edebilmek açısından önemlidir. Kullanılan sözel problemler (Ek-1), işlemle tutarlı anahtar sözcük içeren ve işlemle tutarsız anahtar sözcük içeren olmak üzere iki kategoriden oluşmakta olup öğrencilerin bu türdeki problemlerdeki performansını ve anahtar sözcüklerin performans üzerindeki rolünü belirleyebilmek açısından tercih edilmiştir. İşlemle tutarlı anahtar sözcük içeren sözel problemler, toplama anahtar sözcügü içerip toplama işlemi gerektiren (TT) ve çıkarma anahtar sözcügü içerip çıkarma işlemi gerektiren (ÇÇ) problemler olmak üzere iki gruptan oluşmaktadır. İşlemle tutarsız anahtar sözcükler içeren sözel problemler ise, toplama anahtar sözcüğü içeren ve çıkarma işlemi gerektiren (TÇ) ve çıkarma anahtar sözcüğü içeren ve toplama işlemi gerektiren problemler (ÇT) olmak üzere iki gruptan oluşmaktadır. 9 tane işlemle tutarlı, 9 tane işlemle tutarsız anahtar sözcük içeren sözel problem olmak üzere, toplam 18 problem bulunmaktadır. Her bir problem grubundan örnek sorular Tablo 1'de yer almaktadır.

Tablo I

Veri toplama aracinda yer alan problem türleri ve örnek sorular

\begin{tabular}{lccl}
\hline Problem türü & & Soru sayıSı & \multicolumn{1}{c}{ Örnek soru } \\
\hline $\begin{array}{l}\text { İşlemle tutarlı anahtar sözcük } \\
\text { içeren problemler } \\
\text { (TT ve ÇÇ) }\end{array}$ & TT & 5 & $\begin{array}{l}\text { Bir akvaryumda 12 tane balık vardır. Akvaryuma } 7 \text { balık daha ilave } \\
\text { edilirse akvaryumda kaç balık olur? }\end{array}$ \\
\cline { 2 - 4 } & ÇÇ & 4 & $\begin{array}{l}\text { Mustafa'nın 17 tane pinpon topu vardır. Arkadaşlarıyla oyun oynarken } \\
\text { toplarının } 6 \text { tanesi eksildiğinde kaç pinpon topu kalır? }\end{array}$ \\
\hline $\begin{array}{l}\text { İşlemle tutarsız anahtar } \\
\text { sözcük içeren problemler } \\
\text { (TÇ ve ÇT) }\end{array}$ & TÇ & 5 & $\begin{array}{l}\text { Gizem'in 13 kırmızı tokası ile } 5 \text { mavi tokası vardır. Gizem'in kırmızı } \\
\text { tokaları mavi tokalarından kaç tane fazladır? }\end{array}$ \\
\cline { 2 - 4 } & ÇT & 4 & $\begin{array}{l}\text { Teneffüs zili çaldığında sınıftaki öğrencilerin 16 tanesi bahçeye çıkmış } 4 \\
\text { tanesi sınıfta kalmıştır. Bu sınıfta kaç öğrenci vardır? }\end{array}$ \\
\hline
\end{tabular}

Bir diğer veri toplama aracı ise öğrencilerin Türkçe ve matematik derslerindeki akademik başarılarına ait öğretmen görüşlerini içeren formlardır. Sını öğretmenlerinden, öğrencilerin karne notlarını ve Türkçe ve matematik derslerindeki akademik başarı durumlarını göz önünde bulundurarak, her bir öğrenciye ilişkin düşük, orta ve yüksek düzeyi temsil etmek üzere değerlendirme yapmaları istenmiştir. Değerlendirmeler Türkçe ve matematik dersleri akademik başarısı açısından düşük düzeyde olan öğrenciler için 1 puan, orta düzeyde olan öğrenciler için 2 puan, yüksek düzeyde olan öğrenciler için 3 puan verilerek gerçekleştirilmiştir. Değerlendirme yaparken öğretmenlerden her bir öğrencinin Türkçe ve matematik derslerindeki akademik gelişimini göz önünde bulundurmaları istenmiştir. Öğretmenlerin hem karne notlarını dikkate alması hem de sınıf öğretmeni olmaları sebebiyle öğrencileri en az iki yıldır tanıyor olmaları bu konudaki kararlarının güvenirliği açısından önemli ölçütlerdir. Elde edilen veriler sonucunda Türkçe dersi akademik başarısı düşük 28, orta 31, yüksek 41 öğrenci bulunmaktadır. Matematik dersi akademik başarısı düşük 37, orta 24, yüksek 39 öğrenci bulunmaktadır.

\section{Veri Toplama Aracının Uygulanışı}

Veriler birinci araştırmacı tarafından 2019-2020 eğitim-öğretim yılının güz döneminde, Ekim-Kasım ve Aralık aylarında toplanmıştır. Araştırmanın nicel aşamasına ait veriler kâğıt-kalem uygulaması ile toplanmıştır. Yaklaşık bir ders saati süresinde gerçekleştirilen uygulamada öğrencilere sözel problemlerin yer aldığı form dağıtılmış ve öğrencilerden soruları çözmeleri ve çözümlerini kâğıt üzerinde belirtmeleri istenmiştir. Uygulamalara katılan öğrencilere, öğretmenlere, okul yöneticilerine ve ailelere çalışma hakkında gerekli bilgiler verilmiş ve izinler alınmıştır. Ayrıca öğrenciler araştırma sonucunda elde edilen verilerin okul başarılarını etkilemeyeceği konusunda bilgilendirilmiştir. Kâğıt-kalem uygulaması sınıf öğretmenleri eşliğinde araştırmacı tarafından gerçekleştirilmiştir. Ekim ve Kasım ayları içerisinde araştırmanın nicel aşamasına ait veriler toplanmış olup ilgili analizler gerçekleştirildikten sonra yarı yapılandırılmış görüşme yapılacak öğrenciler belirlenmiştir. Belirlenen öğrencilerle sessiz bir ortamda birebir görüşmeler gerçekleştirilmiş olup bu görüşmeler ses kayıt cihazı ile kayıt altına alınmıştır. Yapılan görüşmeler en kısa 15 dakika, en uzun 45 dakika sürmüştür. Yarı yapılandırılmış görüşme sürecinde öğrencilerin işlemle tutarlı ve 
tutarsız anahtar sözcükler içeren sözel problemleri nasıl çözdükleri, hangi işlemleri kullanmayı tercih ettikleri ve bu işlem tercihlerinde anahtar sözcüklerin rolü incelenmiştir. Bu süreçte öğrencilere, "Bu problemi nasıl çözdüğünü açıklar mısın?”, “Neden bu işlemi yapmayı tercih ettin?” gibi sorular sorulmuş ve öğrencilerin işlem tercihlerinde anahtar sözcüklerin rolü derinlemesine incelenmiştir.

\section{Veri Analizi}

Öğrencilerin problem çözme performansını belirlemek için her bir soruya verdikleri doğru yanıtlar 1 puan, yanlış yanıtlar 0 puan olarak kodlanmıştır. Araştırma sonucunda elde edilen veriler ile öğrencilerin problem çözme performansının belirlenmesi amaçlanmış ve bu performansları akademik başarı değişkeni ile ilişkilendirilmiştir. Bu sebeple öğrencilerin problem çözme performansı doğru ve yanlış yanıtlar üzerinden belirlenmiştir. Veri analizine başlanmadan önce verilerin normal dağılım gösterip göstermediğini test etmek için, basıklık-çarpıklık katsayıları ve mod, medyan ve ortalama değerler incelenmiştir. Basıklık ve çarpıklık katsayılarının +1 ve -1 değerleri arasında olması ve mod-medyan-ortalamanın birbirine yakın olması sebebiyle verilerin normal dağılım gösterdiği tespit edilmiştir. Öğrencilerin problem çözme performanslarının tutarlı ve tutarsız sözcükler içeren problem türlerine göre anlamlı bir farklılaşma gösterip göstermediğini tespit etmek için ilişkili örneklemler için $t$ testi uygulanmıştır. Öğrencilerin işlemle tutarlı ve tutarsız sözcükler içeren sözel problem çözme performansının Türkçe ve matematik dersi akademik başarı düzeylerine göre anlamlı farklılaşma gösterip göstermediği tek faktörlü varyans analizi ile test edilmiştir. Araştırmanın nitel aşamasında elde edilen verilerin analizinde betimsel analiz tekniği kullanılmış olup öğrencilerin problemlere verdikleri yanıtların doğruluk durumu, kullandıkları işlemler, işlem tercihlerinin nedenleri ve anahtar sözcüklerin bu süreçteki rolüne dair görüşleri incelenmiştir. Görüşmeler sonucunda elde edilen veriler her iki araştırmacı tarafından ayrı ayrı kodlanmış ve kodlayıcılar arası güvenirliği sağlayabilmek amacıyla karşılaştırmalar yapılmıştır. Görüş ayrılığı bulunan durumlar üzerinde tartışılmış ve araştırmacılar arasında görüş birliği sağlanmıştır. Daha sonra, elde edilen veriler göz önünde bulundurularak öğrencilerin akademik başarı düzeyi ve sözel problemleri çözerken anahtar sözcüklerden yararlanma durumları arasındaki ilişki betimlenmeye çalışılmıştır. Görüşmeye katılan öğrencilerin isimleri gizli tutulmuş olup her bir öğrenci için Ö1, Ö2, Ö3,...,Ö20 şeklinde kodlama yapılmıştır.

\section{Bulgular}

Öğrencilerin işlemle tutarlı ve tutarsız anahtar sözcükler içeren sözel problemlerdeki performansını yansıtan betimsel değerler Tablo 2'de yer almaktadır. Buna göre öğrencilerin TT ve ÇÇ problemlerinde daha yüksek performans sergiledikleri görülmektedir. Yani anlamsal tutarlılık içeren problemlerde (TTÇÇ) öğrenciler daha yüksek performans gösterirken, anlamsal tutarsızlık içeren sözel problemlerde (TÇÇT) daha düşük performans göstermiştir.

Tablo II

Betimsel Istatistikler

\begin{tabular}{cccccccc}
\hline & TT & ÇÇ & TÇ & ÇT & Tutarli & Tutarsiz \\
\hline N & 100 & 100 & 100 & 100 & 100 & 100 & 0 \\
Ranj & $0-5$ & $0-4$ & $0-5$ & $0-4$ & $0-9$ & $0-9$ & $0-18$ \\
X- & 4.65 & 3.63 & 3.85 & 3.07 & 8.28 & 100 \\
SS & 0.78 & 0.80 & 1.55 & 1.20 & 1.42 & 2.51 \\
\hline
\end{tabular}

Birinci alt problemde öğrencilerin tutarlı ve tutarsız anahtar sözcükler içeren problemlerdeki performansları arasında anlamlı bir farklılaşma görülüp görülmediği incelenmiştir. Her iki problem türüne ait ortalama puanları arasındaki farkın anlamlılı̆̆ı için yapılan $\mathrm{t}$ testi sonuçları Tablo 3 'te yer almaktadır.

\section{Tablo III}

Tutarlı ve tutarsız sözel problem ortalama puanları t testi sonuçları

\begin{tabular}{llllll}
\hline Ölçüm & $\mathrm{N}$ & $\bar{X}$ & $\mathrm{~S}$ & sd & $\mathrm{t}$ \\
\cline { 1 - 1 } TT ve ÇÇ & 100 & 8.28 & 1.42 & 99 & 6.34 \\
\hline TÇ ve ÇT & 100 & 6.92 & 2.51 & & .000 \\
\hline
\end{tabular}


Öğrencilerin işlemle tutarsız anahtar sözcükler içeren problemlerdeki performansında, işlemle tutarlı anahtar sözcükler içeren problemlerdeki performanslarına göre anlamlı bir azalma olduğu görülmüştür $(t(99)=6,34, p<.01)$. Buna göre, öğrencilerin tutarlı anahtar sözcükler içeren problemlerden elde ettiği ortalama puan 8,28 iken tutarsız anahtar sözcükler içeren problemlerden elde ettiği ortalama puan 6,92'ye düşmüştür.

İkinci alt problemde öğrencilerin işlemle tutarlı ve tutarsız anahtar sözcükler içeren sözel problemlerdeki performanslarının matematik ve Türkçe dersi akademik başarılarına göre nasıl farklılaştığı incelenmiştir. Analiz sonuçları öğrencilerin her iki problem türündeki performansının, Türkçe ve matematik dersi akademik başarı gruplarına göre anlamlı şekilde farklılaştı̆̆ını ortaya koymaktadır (Tablo 4 ve Tablo $5)$.

Tablo IV

Öğrencilerin problem çözme puanlarının Türkçe dersi başarı gruplarına göre ANOVA sonuçları

\begin{tabular}{|c|c|c|c|c|c|c|c|c|}
\hline Problem türü & $\begin{array}{l}\text { Varyansın } \\
\text { kaynağı }\end{array}$ & $\begin{array}{l}\text { Kareler } \\
\text { toplamı }\end{array}$ & $\mathrm{sd}$ & $\begin{array}{l}\text { Kareler } \\
\text { ortalaması }\end{array}$ & $\mathrm{F}$ & $\mathrm{p}$ & Anlamlı fark & $\eta 2$ \\
\hline \multirow{3}{*}{ Tutarlı } & Gruplararası & 38.700 & 2 & 19.350 & 11.482 & .000 & $1-2,1-3$ & 0.19 \\
\hline & Gruplariçi & 163.460 & 97 & 1.685 & & & & \\
\hline & Toplam & 202.160 & 99 & & & & & \\
\hline \multirow{3}{*}{ Tutars1z } & Gruplararası & 245.485 & 2 & 122.743 & 31.342 & .000 & $1-2,1-3$ & 0.39 \\
\hline & Gruplariçi & 379.875 & 97 & 3.916 & & & & \\
\hline & Toplam & 625.360 & 99 & & & & & \\
\hline
\end{tabular}

Türkçe dersi akademik başarı grupları değişkeninin işlemle tutarlı ve tutarsız anahtar sözcükler içeren sözel problemlerde öğrencilerin performanslarına etkisini incelemek amacıyla gerçekleştirilen analiz sonuçlarına göre (Tablo 4), öğrencilerin işlemle tutarlı ve tutarsız anahtar sözcük içeren problem gruplarından elde ettikleri ortalama puanlar, Türkçe dersi akademik başarı gruplarına göre anlamlı şekilde farklılaşmıştır (tutarlı- $\mathrm{F}(2,97)=11,482, \mathrm{p}<.01$; tutarsız- $\mathrm{F}(2,97)=31,342, \mathrm{p}<.01$ ). Türkçe dersi akademik başarısı açısından hangi gruplar arasında fark olduğunu bulmak amacıyla yapılan Scheffe testi sonuçlarına göre, düşük grupta yer alan öğrencilerin performansının orta ve yüksek gruptaki öğrencilerin performansından anlamlı bir farkla daha düşük olduğu görülmüş olup her bir grubun ortalama puanı Tablo 6'da yer almaktadır.

Tablo V

Öğrencilerin problem çözme puanlarının Matematik dersi başarı gruplarına göre ANOVA sonuçları

\begin{tabular}{|c|c|c|c|c|c|c|c|c|}
\hline $\begin{array}{l}\text { Problem } \\
\text { türü }\end{array}$ & $\begin{array}{l}\text { Varyansın } \\
\text { kaynağı }\end{array}$ & $\begin{array}{l}\text { Kareler } \\
\text { toplam }\end{array}$ & sd & $\begin{array}{l}\text { Kareler } \\
\text { ortalaması }\end{array}$ & F & $\mathrm{p}$ & $\begin{array}{l}\text { Anlamlı } \\
\text { fark }\end{array}$ & $\eta 2$ \\
\hline \multirow{3}{*}{ Tutarlı } & Gruplararası & 37.224 & 2 & 18.612 & 10.946 & .000 & $1-2,1-3$ & 0.18 \\
\hline & Gruplariçi & 164.936 & 97 & 1.700 & & & & \\
\hline & Toplam & 202.160 & 99 & & & & & \\
\hline \multirow{3}{*}{ Tutarsız } & Gruplararası & 226.427 & 2 & 113.214 & 27.528 & .000 & $1-2,1-3$ & 0.36 \\
\hline & Gruplariçi & 398.933 & 97 & 4.113 & & & & \\
\hline & Toplam & 625.360 & 99 & & & & & \\
\hline
\end{tabular}

Matematik dersi akademik başarı grupları değişkeninin ilkokul öğrencilerinin işlemle tutarlı ve tutarsız anahtar sözcükler içeren sözel problemlerdeki performanslarına etkisini incelemek amacıyla yapılan analiz sonuçlarına göre (Tablo 5), öğrencilerin işlemle tutarlı ve tutarsız anahtar sözcükler içeren problem gruplarından elde ettikleri ortalama puanlar, matematik dersi akademik başarı gruplarına göre anlamlı şekilde farklılaşmıştır (tutarl1- $\mathrm{F}(2,97)=10,946, \mathrm{p}<.01$; tutarsız- $\mathrm{F}(2,97)=27,528, \mathrm{p}<.01$ ). Matematik dersi akademik başarısı açısından hangi gruplar arasında fark olduğunu bulmak amacıyla yapılan Scheffe testi sonuçlarına göre, düşük grupta yer alan öğrencilerin performansının orta ve yüksek gruptaki öğrencilerin performansından anlamlı bir farkla daha düşük olduğu görülmüş olup her bir grubun ortalama puanı Tablo 6'da yer almaktadır. Tablo 4 ve Tablo 5 'te yer alan eta-kare değerleri bağımlı değişken üzerindeki toplam varyansın ne kadarının bağımsız değişken tarafından açıklandığını göstermektedir. Buna göre, .06'ya kadar küçük, .14'e kadar orta, .14'ün üzeri ise büyük etki büyüklügünden söz etmek mümkündür (Cohen, 1988). Öğrencilerin Türkçe ve matematik dersleri açısından düşük düzey akademik başarıya sahip olmasının 
tutarlı ve tutarsız anahtar sözcükler içeren problemlerdeki performanslarına olan etkisi büyük etki büyüklüğü ile açılanmaktadır. Ancak, tutarlı anahtar sözcükler içeren problemlerde bu etki varyansın yaklaşık \%20'si ile açıklanırken (Türkçe dersi için $\eta^{2}=.19$, matematik dersi için $\eta^{2}=.18$ ) tutarsız anahtar sözcükler içeren problemlerde yaklaşık $\% 40^{\prime} 1$ ile (Türkçe dersi için $\eta^{2}=.39$, matematik dersi için $\eta^{2}=.36$ ) açılanmıştır. Buna göre akademik başarı değişkeninin özellikle tutarsız anahtar sözcükler içeren sözel problemlerdeki performansa etkisinin daha fazla olduğunu söylemek mümkündür.

Tablo VI

Ortalama puanların başarı gruplarına göre betimsel istatistikleri

\begin{tabular}{llllllllllcc}
\hline \multicolumn{2}{c}{ Türkçe dersi için; } & \multicolumn{2}{c}{ Tutarl } & \multicolumn{2}{c}{ Tutarsız } & \multicolumn{2}{c}{ Matematik dersi için; } & \multicolumn{2}{c}{ Tutarlı } & \multicolumn{2}{c}{ Tutarsız } \\
\hline & $\mathrm{N}$ & $\overline{\mathrm{x}}$ & SS & $\overline{\mathrm{x}}$ & SS & & $\mathrm{N}$ & $\overline{\mathrm{x}}$ & SS & $\overline{\mathrm{x}}$ & SS \\
Düşük & 28 & 7.32 & 2.16 & 4.50 & 2.79 & Düşük & 37 & 7.49 & 2.02 & 5 & 2.63 \\
Orta & 31 & 8.42 & 0.99 & 7.29 & 2.02 & Orta & 24 & 8.67 & 0.63 & 7.54 & 2.17 \\
Yüksek & 41 & 8.83 & 0.44 & 8.29 & 1.07 & Yüksek & 39 & 8.79 & 0.46 & 8.36 & 1.03 \\
\hline
\end{tabular}

Üçüncü alt problemde ilkokul 3. ve 4. sınıf öğrencilerinin işlemle tutarlı ve tutarsız anahtar sözcükler içeren sözel problemlerdeki performansı üzerinde anahtar sözcüklerin rolü incelenmiştir. Anlamsal açıdan tutarlı anahtar sözcüklerin yer aldığı sözel problemlerde 9 soru bulunmakta olup soruların 5 tanesi (TT-1, 4, 8, 15, 19 numaralı sorular) toplama işlemi ile tutarlı sözcükler içermekte ve toplama işlemi yapmayı gerektirmektedir. 4 soru (2, 11, 14 ve 18 numaralı sorular) ise çıkarma işlemi ile tutarlı sözcükler içerip çıarma işlemi yapmayı gerektirmektedir. Özellikle TT problemlerinde öğrencilerin performansının diğer problem türlerine göre daha yüksek olduğuna betimsel istatistikler sonucu ulaşılmıştır. Dolayısıyla bu gruptaki sorulara daha az öğrenci yanlış cevap vermiştir. Türkçe ve matematik dersi akademik başarısı ve problem çözme performansı açısından düşük, orta ve yüksek düzeyde bulunan öğrenci gruplarıyla yapılan yarı yapılandırılmış görüşmeler sonucu öğrencilerin işlem seçimleri ve bu işlem seçimlerini etkileyen faktörler incelenmiştir. TT problemlerinden 1. soruya kâğıt-kalem uygulamasında 3 öğrenci (Ö9, Ö1, Ö10) yanlış cevap vermiştir. Görüşmeler esnasında öğrencilerden soruyu tekrar incelemeleri ve çözmeleri istendiğinde ise 1 öğrenci (Ö14) dışında diğer tüm öğrenciler toplama işlemi yapılacağı konusunda görüş bildirmiştir. Öğrencilere neden toplama işlemi yapılacağını düşündükleri sorulduğunda, "Çünkü toplam diyor.", "Çünkü artıyor." gibi yanıtlar vermişlerdir. Öğrencilerin büyük bir kısmının doğru işlemi tercih ettiği ve bu tercihlerinin sebebini "toplam" anahtar sözcüğü ile açıkladıkları söylenebilir. Ö2 kodlu öğrenciye neden toplama işlemi yapmayı tercih ettiği sorulduğunda "Çünkü gittiğini söylemiyor. Kaç papağan gördüğünü söylüyor yani topluyor. Yani papağanların yok olduğunu söylemiyor. $O$ yüzden çıkarma yapmayız." şeklinde cevap vermiştir. Bu öğrencinin "Gittiğini söylemiyor, yani papağanların yok olduğunu söylemiyor." şeklindeki ifadesi ile çıkarma işlemini uygun bulmadığını açıklaması, öğrencinin anahtar sözcüğe dayalı olarak işlem seçiminde bulunduğunun bir kanıtıdır. 4. soruyu kâğıt-kalem uygulamasında 2 öğrenci (Ö11, Ö7) yanlış cevaplamıştır. Görüşmeler esnasında öğrencilerden soruyu tekrar incelemeleri ve çözmeleri istendiğinde öğrencilerin tamamının toplama işlemi yapılacağını belirttiği görülmüştür. Neden toplama işlemi yapmayı tercih ettikleri sorulduğunda anahtar sözcüklere yaptıkları vurgular dikkat çekmektedir.

Ö1 kodlu öğrenciye aynı soru yöneltildiğinde bu öğrenci toplama işlemini tercih etmesinin sebebini "Burada çok balık var, o zaman toplamamız gerekiyor." şeklinde açıklamıştır. Hangi durumlarda toplama işlemi yaptığımız sorulduğunda "Mesela böyle bir tane sepet var. İçinde böyle çok top var onları toplayabiliriz mesela. Çünkü çok top var." şeklinde açıklamıştır. Bu öğrencinin toplama ile çok ifadesini bağdaştırdığı söylenebilir. 8. soruyu kâğıt-kalem uygulamasında 1 öğrenci (Ö6) yanlış cevaplamıştır. Görüşmeler esnasında öğrencilerden soruyu tekrar incelemeleri ve çözmeleri istendiğinde yine Ö6 kodlu öğrenci dışında diğer öğrencilerin toplama işlemi yapılacağını belirttikleri görülmüştür. Öğrencilere işlem seçimlerinin gerekçeleri sorulduğunda "Çünkü 9'un üstüne 8 daha eklemiş.", "Çünkü toplam kaç kitab1 vardır diyor." şeklinde cevaplar vermişlerdir. 15. soruyu kâğıt-kalem uygulamasında 4 öğrenci (Ö2, Ö11, Ö6, Ö7) yanlış cevaplamıştır. Görüşmeler esnasında öğrencilerden soruyu tekrar incelemeleri ve çözmeleri istendiğinde öğrencilerin neredeyse tamamı toplama işlemi yapılacağını anahtar sözcüklere vurgu yaparak ifade etmişlerdir. 
İşlemle tutarlı anahtar sözcükler içeren bir diğer problem grubu ÇÇ problemleridir. 2, 11, 14 ve 18 numaralı sorular bu problem grubundadır. 2. soruyu kâğıt-kalem uygulamasında 4 öğrenci (Ö1, Ö2, Ö3, Ö12) yanlış cevaplamıştır. Görüşmeler esnasında öğrencilerden soruyu tekrar incelemeleri ve çözmeleri istendiğinde ise Ö3 kodlu öğrenci yazılı cevabına benzer şekilde yanlış cevap vermiş, Ö15 kodlu öğrenci ise görüşme esnasında soruyu yanlış cevaplamıştır. Her iki öğrenci de çarpma işlemi yapılacağını ifade etmiş ve gerekçesini tam olarak açıklayamamışlardır. Ancak söylemlerinden "Ahmet'in 16 tane oyun kartı vardır. Oyun kartlarının 4 tanesini arkadaşlarına verdiğinde kaç tane oyun kartı kalmıştır?" sorusunu 4 kişinin her birinde 16 kart olduğunu düşünerek yorumladıkları görülmektedir. Ö2 kodlu öğrenciye kâğıt-kalem uygulamasında neden toplama işlemi yaptığı sorulduğunda "Öğretmenim galiba ben hepsini toplama sanmışım." yanıtını vermiştir. Doğru cevap veren öğrencilere işlem seçimlerinin gerekçeleri sorulduğunda genellikle anahtar sözcüğe vurgu yapmışlardır. Öğrencilerden gelen yanıtlardan bazıları "Çünkü 4 tanesini arkadaşlarına verdiğine göre azalıyor misketleri. (Ö1)", "Çünkü azalıyor arkadaşlarına veriyor 4 tanesini. (Ö4)" şeklindedir.

11. soruyu kâğıt-kalem uygulamasında 4 öğrenci (Ö2, Ö6, Ö8, Ö13) yanlış cevaplamıştır. Görüşmeler esnasında öğrencilerden soruyu tekrar incelemeleri ve çözmeleri istendiğinde öğrenciler sorunun çözümü için çıkarma işlemi yapılacağını fark etmiştir. Öğrencilerin tamamı neden çıkarma işlemi yapılacağını "eksildiği için, azaldığı için" şeklinde ifadelerle açıklamışlardır.

14. soruyu kâğıt-kalem uygulamasında 3 öğrenci (Ö4, Ö6, Ö7) yanlış cevaplamıştır. Görüşmeler esnasında öğrencilerden soruyu tekrar incelemeleri ve çözmeleri istendiğinde öğrencilerin tamamı çıarma işlemi yapılacağını ifade etmiş ve gerekçe olarak "eksildiği için” anahtar sözcüğüne vurgu yapmışlardır:

7 tane eksilmiş olduğu için. (Ö10)

Eğer 9 tane boncuk getirdiyse ve kardeşler sabah kalktıklarında boncukların 7 tanesinin eksilmiş olduğunu görürlerse 9'dan 7'yi çıkarırım. ( Ö16)

2 tane kalmıştır. Çünkü çıkarma. Annesi 9 tane getirmiş sabah kalktı̆̆ında 7 tane eksik olduğunu görmüş. (Ö4)

18. soruyu kâğıt-kalem uygulamasında 3 öğrenci (Ö2, Ö6, Ö7) yanlış cevaplamıştır. Görüşmeler esnasında öğrencilerden soruyu tekrar incelemeleri ve çözmeleri istendiğinde öğrencilerin tamamı çıarma işlemi yapılacağını ifade etmiştir. Öğrencilere işlem seçimlerinin gerekçesi sorulduğunda, "çıktığında" anahtar sözcügüne vurgu yaptıkları görülmektedir.

Gerek toplama anahtar sözcüğü içeren ve toplama işlemi yapmayı gerektiren, gerekse çıkarma anahtar sözcüğü içeren ve çıkarma işlemi yapmayı gerektiren anlamsal açıdan işlemle tutarlı anahtar sözcükler içeren sözel problemlerde öğrencilerin geneli soruları çözmek için gerekli işlem seçimlerini doğru yönde yapmışlardır. Belirttikleri işlemi tercih etme sebeplerini açıklarken problemlerde yer alan anahtar sözcüklere vurgu yapmaları dikkat çekmektedir. Aynı öğrencilerin anlamsal açıdan tutarsız problemlerde işlem tercihlerini neye dayalı olarak gerçekleştireceklerini incelemek amacıyla öğrencilerle yarı yapılandırılmış görüşmeler gerçekleştirilmiştir. İşlemle tutarsız anahtar sözcük içeren sözel problem grubunda 9 soru bulunmakta olup bu problemlerden 5 tanesi toplama anahtar sözcüğü içermekte ve çıkarma işlemi yapmayı gerektirmektedir. 4 problem ise çıkarma anahtar sözcüğü içermekte ve toplama işlemi yapmayı gerektirmektedir. Toplama anahtar sözcügü içerip çıkarma işlemi yapmayı gerektiren sorular 5, 7, 9, 13 ve 17 numaralı sorulardır. 5. soruyu kâğıt-kalem uygulamasında 11 öğrenci yanlış cevaplamıştır. Görüşmeler esnasında öğrencilerden soruyu tekrar incelemeleri ve çözmeleri istendiğinde bir grup öğrenci soruyu doğru cevaplarken bir grup öğrenci araştırmacının yönlendirmesi ile doğru sonuca ulaşmış, ancak cevabından çok emin olamamıştır. Öğrencilerin bir kısmı ise "toplam, artmıştır" gibi anahtar sözcüklere bağlı kalarak toplama işlemi yapacağını ifade etmiştir. Soruyu doğru cevaplayan öğrenciler çıkarma işlemi yapılması gerektiğinin sebebini, "Keklerin 4 tanesi artmıştır." ifadesi ile açıklamışlardır. Bu öğrencilere göre "Keklerin 4 tanesi artmıştır." ifadesi geriye kalan kekleri temsil etmektedir.

Bir grup öğrenci (örneğin, Ö10, Ö6, Ö3, Ö6, Ö11) ise "toplam, artmıştır" anahtar sözcüklerinden dolay1 toplama işlemi yapacağını ifade etmiştir. Neden toplama işlemi yapmayı tercih ettiğini Ö3 kodlu öğrenci "Çünkü toplam 17 tanedir diyor. O yüzden toplayacağım." şeklinde, Ö6 kodlu öğrenci "Toplam dediği için." şeklinde belirtmiştir. 
7. soruyu kâğıt-kalem uygulamasında 6 öğrenci yanlış cevaplamıştır. Görüşmeler esnasında öğrencilerden soruyu tekrar incelemeleri ve çözmeleri istendiğinde, Ö6 kodlu öğrenci soruyu yapamamış, Ö2 ve Ö11 kodlu öğrenciler ise toplama yapılması gerektiğini ifade etmişlerdir. Diğer öğrenciler problemde geçen "gelmemiştir" ifadesi sebebiyle çıkarma işlemi yapılacağını belirtmiştir. Toplama işlemi yapılacağını belirten iki öğrenci "toplam" ifadesinden dolayı bu işlemi tercih ettiklerini ifade etmişlerdir. Örneğin Ö3 kodlu öğrenci "Çünkü şurada toplam 3 tanesi gelmemiştir. Toplam dediği için toplama yapmalıyız." şeklinde görüşünü belirtmiştir. 9. soruyu kâğıt-kalem uygulamasında 11 öğrenci yanlış cevaplamıştır. Görüşmeler esnasında öğrencilerden soruyu tekrar incelemeleri ve çözmeleri istendiğinde, Ö1, Ö3, Ö12, Ö7, Ö8, Ö9 kodlu öğrenciler toplama işlemi yapılacağını ifade etmiştir. Ö6 kodlu öğrenci soruyu cevaplayamamıştır. Diğer öğrenciler ise çıkarma işlemi yapılacağını ifade etmiş̧tir. Örneğin, Ö9 kodlu öğrenci problemde geçen "fazladır" ifadesinden dolayı toplama işlemi yapılması gerektiğini belirtmiştir. Ö3 kodlu öğrenci toplama işlemi yapmayı tercih etmesinin sebebini "13 ile 5’i toplayacağız. Çünkü 13 tane kırmızı tokası varmış 5 mavi tokası varmış. Gizem'in kırmızı tokaları mavi tokalarından kaç fazladır dediği için." şeklinde ifade etmiştir.

13. soruyu kâğıt-kalem uygulamasında 9 öğrenci yanlış cevaplamıştır. Görüşmeler esnasında öğrencilerden soruyu tekrar incelemeleri ve çözmeleri istendiğinde Ö3, Ö7, Ö8, Ö9 kodlu öğrenciler toplama işlemi yapılacağını ifade etmiştir. Bir önceki soruyla benzer nitelikte olan bu soruda bir grup öğrenci çıkarma işlemi yapılacağını sorular arasındaki benzerlikten dolayı fark etmiştir. Belirtilen dört öğrenci ise neden toplama işlemi yapılması gerektiğini, bir önceki soruda da olduğu gibi "Kaç tane fazladır?" ifadesini gerekçe göstererek açıklamıştır. 17. soruyu kâğıt-kalem uygulamasında 11 öğrenci yanlış cevaplamıştır. Görüşmeler esnasında öğrencilerden soruyu tekrar incelemeleri ve çözmeleri istendiğinde aynı sayıda öğrenci toplama işlemi yapılacağını belirtmiştir. Örneğin, Ö1 kodlu öğrenci neden toplama işlemini tercih ettiğini "Çünkü daha katılınca diyor.", Ö2 kodlu öğrenci "Çünkü daha fazla gül koymuş." şeklinde ifade etmiştir. Toplama işlemini tercih eden öğrenciler gerekçelerini açıklarken katılma ifadesine ve gül sayısındaki artışa dikkat çekerek anahtar sözcüklere vurgu yapmışladır.

3, 6, 12 ve 16 numaralı sorular ise çıkarma anahtar sözcüğü içermekte ve toplama işlemi yapmayı gerektirmektedir. 3. soruyu kâğıt-kalem uygulamasında 11 öğrenci yanlış cevaplamıştır. Görüşmeler esnasında öğrencilerden soruyu tekrar incelemeleri ve çözmeleri istendiğinde yine 11 öğrenci çıkarma işlemi yapılacağın belirtmiş, 1 öğrenci ise cevap verememiştir. Örneğin, Ö1 kodlu öğrenci neden çıkarma işlemi yapılacağını "Çünkü bazı öğrenciler dışarı çıktığı için içerdeki öğrenciler azalıyor." şeklinde açıklamıştır. Ö10 kodlu öğrenci 16 tanesi bahçeye çıktığı ve 4 tanesi sınıfta kaldığı için çıkarma işlemi yapacağını belirtmiştir. Çıkarma işlemi yapmayı tercih eden öğrencilerin büyük bir kısmı "bahçeye çıkma" ifadesi ile işlem seçimlerinin nedenini açıklamışlardır.

6. soruyu kâğıt-kalem uygulamasında 9 öğrenci yanlış cevaplamıştır. Görüşmeler esnasında öğrencilerden soruyu tekrar incelemeleri ve çözmeleri istendiğinde 14 öğrenci 1 cevabını vermiş ve 8 'den 7'yi çıkarmıştır. Öğrencilere işlem seçimlerinin gerekçeleri sorulduğunda öğrencilerin geneli eksilme anahtar sözcügü sebebiyle bu işlemin yapılması gerektiğini şu şekilde ifade etmiştir:

\footnotetext{
“Şimdi biz bunu bulmak için çıkartırız. Çünkü 8 tane eksilince diyor. 8 tane eksilirse 8'den $\quad$ 7'yi çıkartacağız." (Ö1)

"8 tanesi eksilince 7 tanesi kalıyor, yani çıkartma yapmalıyı.." (Ö2)

"Funda'nın tokaları 8 tane eksilince 7 tane tokası kalıyor yani 8'den 7'yi çıkaracağız. 1 tane tokası eksikmiş kaybolmuş." (Ö17)
}

12. soruyu kâğıt-kalem uygulamasında 10 öğrenci yanlış cevaplamıştır. Görüşmeler esnasında öğrencilerden soruyu tekrar incelemeleri ve çözmeleri istendiğinde Ö11, Ö3, Ö8 kodlu öğrenciler çıkarma işlemi yapılacağını ifade etmiş, diğer öğrenciler doğru yanıt vermiştir. Bu soruya doğru yanıt veren öğrenci sayısındaki artışın sebebi 6 numaralı soruda benzer içerikte bir problemle karşılaşmaları ile açıklanabilir. Ö6 kodlu öğrenci bu durumu "biraz önceki sınıf sorusu" şeklinde ifade etmiş ve kâğıt-kalem uygulamasında soruyu yanlış cevaplamasına rağmen görüşme sürecinde hatasını fark etmiş ve toplama işlemi yapılması gerektiğini ifade etmiştir. 16. soruyu kâğıt-kalem uygulamasında 10 öğrenci yanlış cevaplamıştır. Görüşmeler esnasında öğrencilerden soruyu tekrar incelemeleri ve çözmeleri istendiğinde Ö1, Ö11, Ö3, Ö6 
ve Ö19 kodlu öğrenciler "eksildiğinde" anahtar sözcüğü sebebiyle çıkarma işlemi yapacaklarını ifade etmişlerdir. Örneğin, Ö1 kodlu öğrenci "Çıkartacağız çünkü eksildiğinde diyor." sözleriyle anahtar sözcüğe vurgu yapmıştır. Ö19 kodlu öğrenci bu durumu “9'dan 7'yi çıkaracağız. Bir tabakta 7 kurabiye eksildiğinde tabakta 9 kurabiye kalıyor. Bize kaç tane kurabiye vardır diyor. Bu yüzden 9'dan 7'yi çıkararak tabakta kaç tane kurabiye kaldığını bulabiliriz." şeklinde ifade etmiştir.

Yapılan analizler sonucunda, öğrencilerin genellikle hem işlemle tutarlı hem de tutarsız anahtar sözcük içeren problem türlerinde anahtar sözcüklere vurgu yaptıkları görülmektedir. Öğrencilerin anahtar sözcüklere odaklanması, özellikle işlemle tutarsız anahtar sözcükler içeren sözel problemlerde yanlış işlem tercihinde bulunmalarına sebep olmaktadır. Tablo 4 ve Tablo 5 'te yer alan veriler incelendiğinde, öğrencilerin Türkçe ve matematik dersleri akademik başarı gruplarına göre problem çözme performanslarının farklılaştığı görülmüştür. Düşük gruptaki öğrenciler ile diğer öğrenciler arasında görülen bu farklılaşma özellikle işlemle tutarsız anahtar sözcük içeren sözel problemlerde daha fazladır. Buna göre, mülakata katılan öğrencilerin Türkçe ve matematik dersleri akademik başarısı açısından farklı düzeylerde olmasına özen gösterilmiştir. Böylece farklı başarı gruplarındaki öğrencilerin özellikle işlemle tutarsız anahtar sözcükler içeren problemlerde anahtar sözcüklerden etkilenme durumu daha açı ortaya konulmaya çalışılmıştır. Bu kapsamda, yarı yapılandırılmış görüşmeye katılan farklı düzeylerde akademik başarıya sahip öğrencilerin, problem çözme performansının problem türlerine göre nasıl değiştiğine dair veriler Tablo 7'de sunulmuştur.

\section{Tablo VII}

Tutarlı $(T T, C ̧ C ̧)$ ve tutarsız (TÇ, ÇT) problem türlerine göre yanlış işlem tercihinde bulunan öğrenci sayıları

\begin{tabular}{|c|c|c|c|c|c|c|c|}
\hline \multirow{3}{*}{ Problem Türü } & \multirow{3}{*}{ Soru no } & \multicolumn{3}{|c|}{ Kâğıt-kalem uygulamasında } & \multicolumn{3}{|c|}{ Yarı yapılandırılmış görüşmelerde } \\
\hline & & Düşük & Orta & Yüksek & Düşük & Orta & Yüksek \\
\hline & & $\mathrm{f}$ & $\mathrm{f}$ & $\mathrm{f}$ & $\mathrm{f}$ & $\mathrm{f}$ & $\mathrm{f}$ \\
\hline \multirow{5}{*}{$\mathrm{TT}$} & 1 & 2 & 1 & - & - & 1 & - \\
\hline & 4 & 1 & 1 & - & - & - & - \\
\hline & 8 & 1 & - & - & 1 & - & - \\
\hline & 15 & 3 & 1 & - & 1 & - & - \\
\hline & 19 & 4 & 1 & - & - & - & - \\
\hline \multirow{4}{*}{ ÇÇ } & 2 & 3 & 1 & - & 1 & 1 & - \\
\hline & 11 & 3 & 1 & - & - & - & - \\
\hline & 14 & 3 & - & - & - & - & - \\
\hline & 18 & 3 & - & - & - & - & - \\
\hline \multirow{5}{*}{$\mathrm{TÇ}$} & 5 & 6 & 4 & 1 & 3 & 3 & - \\
\hline & 7 & 5 & 1 & - & 3 & - & - \\
\hline & 9 & 8 & 3 & - & 6 & 1 & - \\
\hline & 13 & 6 & 3 & - & 7 & - & - \\
\hline & 17 & 8 & 3 & - & 9 & 3 & - \\
\hline \multirow{4}{*}{ ÇT } & 3 & 6 & 5 & - & 7 & 4 & - \\
\hline & 6 & 4 & 4 & 1 & 8 & 4 & 3 \\
\hline & 12 & 7 & 3 & - & 2 & 1 & - \\
\hline & 16 & 6 & 3 & 1 & 4 & 1 & 1 \\
\hline
\end{tabular}

Akademik başarı açısından düşük düzeyde 9, orta düzeyde 6 ve yüksek düzeyde 5 öğrenci ile yarı yapılandırılmış görüşmeler gerçekleştirilmiştir. Öğrencilerin işlem tercihlerindeki hataların problem türlerine göre dağılımı incelendiğinde, tutarsız anahtar sözcük içeren problem grubundaki öğrenci oranlarının fazlalığı dikkat çekmektedir. Genellikle akademik başarı açısından düşük ve orta grupta bulunan öğrencilerin bu problem türlerinde hatalı işlem tercihinde bulundukları görülmektedir. Bu durum anlamsal tutarsızlığın daha çok düşük ve orta başarı grubundaki öğrencilerin problem çözme performansını olumsuz yönde etkilediğinin bir göstergesidir. Görüşmeye katılan öğrencilerin tutarlı ve tutarsız problemlerdeki başarı yüzdeleri hesaplanmış ve elde edilen verilere Tablo 8'de yer verilmiştir.

\section{Tablo VIII}

Farklı akademik başarı gruplarındaki öğrencilerin tutarlı ve tutarsız problemlerdeki performansı

\begin{tabular}{|c|c|c|c|c|c|c|c|c|}
\hline \multirow{2}{*}{ 馬 } & \multicolumn{2}{|c|}{ Düşük başarı grubu } & \multirow{2}{*}{ 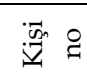 } & \multicolumn{2}{|c|}{ Orta başarı grubu } & \multirow{2}{*}{ 可 } & \multicolumn{2}{|c|}{ Yüksek başarı grubu } \\
\hline & tutarli & tutarsiz & & tutarl1 & tutarsiz & & tutarl1 & tutarsiz \\
\hline
\end{tabular}




\begin{tabular}{|c|c|c|c|c|c|c|c|c|c|c|c|c|c|c|}
\hline & $\mathrm{f}$ & $\%$ & $\mathrm{f}$ & $\%$ & & $\mathrm{f}$ & $\%$ & $\mathrm{f}$ & $\%$ & & $\mathrm{f}$ & $\%$ & $\mathrm{f}$ & $\%$ \\
\hline Ö1 & 7 & 78 & 1 & 11 & Ö10 & 8 & 89 & 2 & 22 & Ö16 & 9 & 100 & 9 & 100 \\
\hline Ö2 & 4 & 44 & 2 & 22 & Ö11 & 7 & 78 & 6 & 67 & Ö17 & 9 & 100 & 9 & 100 \\
\hline Ö3 & 8 & 89 & 1 & 11 & Ö12 & 7 & 78 & 6 & 67 & Ö18 & 9 & 100 & 9 & 100 \\
\hline Ö4 & 7 & 78 & 3 & 33 & Ö13 & 8 & 89 & 5 & 56 & Ö19 & 9 & 100 & 5 & 56 \\
\hline Ö5 & 9 & 100 & 5 & 56 & Ö14 & 9 & 100 & 4 & 44 & Ö20 & 9 & 100 & 9 & 100 \\
\hline Ö6 & 3 & 33 & 3 & 33 & Ö15 & 9 & 100 & 4 & 44 & & & & & \\
\hline Ö7 & 4 & 44 & 4 & 44 & & & & & & & & & & \\
\hline Ö8 & 8 & 89 & 0 & 0 & & & & & & & & & & \\
\hline Ö9 & 8 & 89 & 4 & 44 & & & & & & & & & & \\
\hline
\end{tabular}

Analiz sonuçlarına göre, düşük başarı grubunda bulunan 9 öğrenciden 6'sının performansında tutarsızlık durumuna bağlı olarak önemli azalma olduğu görülmüştür. Ö2, Ö6 ve Ö7 kodlu öğrenciler ise genellikle her iki problem durumunda da az sayıda soruya doğru yanıt verebilmiştir. Orta başarı grubundaki öğrencilerden Ö10, Ö13, Ö14 ve Ö15 kodlu öğrencilerin işlemle tutarlı olmayan anahtar sözcükler içeren sözel problemlerdeki performansındaki düşüş de dikkat çekicidir. Yüksek düzey başarı grubundaki öğrencilerden çoğu problemlerin tamamına doğru yanıt vermiştir. Başarı grupları, öğrencilerin karne notları da göz önünde bulundurularak öğretmenler tarafından yapılan değerlendirmelere göre oluşturulmuştur. Öğretmenlerin değerlendirmeleri ile öğrencilerin problem çözme performansları arasında paralellik olduğunu söylemek mümkündür. Ancak her iki problem grubunda da düşük performans sergileyen bazı öğrencilerin durumunu tek başına tutarsızlık etkisi ile açıklamak mümkün olmayabilir.

\section{Sonuç, Tartışma ve Öneriler}

Sözel problem çözme, işleyen bellek, okuduğunu anlama gibi farklı becerilerin ve işlevlerin kombinasyonunu gerektirmekte olup sözel problem çözme yaklaşımı, problem çözme başarısını etkilemektedir (De Corte ve diğerleri, 1990; Kintsch ve Greeno, 1985; Pape, 2003; Verschaffel ve diğerleri, 1992). Sözel problem çözme yaklaşımını etkileyen önemli faktörlerden birisi tutarlılık etkisi olarak tanımlanmaktadır (de Koning ve van der Schoot, 2020; Verschaffel ve diğerleri, 1992). Bu araştırmada, sözel problemlerin işlemle tutarlı ve tutarsız anahtar sözcükler içeren türlerinde öğrencilerin performanslarının Türkçe ve matematik dersi akademik başarılarına göre nasıl değiştiğinin ve performanslar üzerinde anahtar sözcüklerin rolünün incelenmesi amaçlanmıştır. Öğrenciler Türkçe ve matematik derslerine ait okul başarılarına göre düşük, orta ve yüksek olmak üzere üç grupta değerlendirilmiştir. Araştırmaya hem Türkçe hem de matematik derslerinde düşük başarıya sahip öğrencilerin problem çözme performansı üzerinde tutarlılık etkisinin daha belirgin olacağı hipotezi ile başlanmıştır. Araştırma sonucunda, anlamsal olarak işlemle tutarlı anahtar sözcükler içeren problemlerde (TTÇÇ) öğrenciler daha yüksek performans gösterirken, anlamsal açıdan işlemle tutarsız anahtar sözcükler içeren sözel problemlerde (TÇÇT) daha düşük performans göstermiştir. Soylu (2007) tarafından yapılan araştırma sonucunda ortaokul öğrencilerinin TÇÇT problemlerinde hata kaynaklarının işlem tercihleriyle ilgili olduğu tespit edilmiştir. İşlem seçimlerinde hata yapan öğrencilerle yapılan görüşmeler sonucunda öğrencilerin anahtar sözcükleri göz önünde bulundurdukları tespit edilmiştir. Hegarty ve diğerleri (1995) tarafından yapılan araştırma sonucunda üniversite öğrencilerden başarısız problem çözücülerin, işlemle tutarsız anahtar sözcükler içeren problemlere göre daha yüksek oranda hata yaptıkları görülmüş̧ür. Ayrıca başarısız problem çözücüler sözel problemlerde sayılara ve anahtar sözcüklere daha çok odaklanmıştır. Bu durum tutarsız problemlerdeki performanslarını olumsuz yönde etkilemiştir. van der Schoot ve diğerleri (2009) tarafından yapılan araştırma sonucunda 10-12 yaşlarındaki öğrencilerin problem çözme performansı üzerinde tutarlılık etkisinin olduğu tespit edilmiştir. Boonen ve diğerleri (2016) tarafından yapılan araştırmada da öğrenciler standart bir test sonucuna dayalı olarak başarılı ve daha az başarılı problem çözücüler olarak sınıflandırılmış ve sözel problem çözme becerileri üzerinde tutarlılık etkisi incelenmiştir. Araştırma sonucunda, daha az başarılı problem çözücülerin işlemle tutarsız anahtar sözcükler içeren problemlerin çözümünde zorlandıkları görülmüştür. İlkokul öğrencileriyle yapılan bu araştırma sonucunda da benzer bulgulara ulaşılmıştır. Çelik ve Taşkın (2015) tarafından yapılan çalışmada 11-13 yaş aralığındaki öğrencilerin işlemle tutarlı ve tutarsız anahtar sözcükler içeren problemlerde problem çözme süreçleri incelenmiştir. Araştırma sonucunda öğrencilerin tutarlı dil kullanılarak oluşturulmuş sözel problemleri çözmede tutarsız dil kullanılarak ifade 
edilen problemlere oranla daha başarılı oldukları sonucuna ulaşılmıştır. Dolayısıyla, farklı yaş gruplarıyla gerçekleştirilen araştırma sonuçları göz önünde bulundurulduğunda, yaş ve sınıf seviyelerindeki artışın öğrencilerin anahtar sözcüklere odaklanma durumlarının önüne geçemediği ve tutarlılık etkisinin devam ettiği söylenebilir. İlerleyen yaşlarda görülmeye devam eden bu durumun önüne geçebilmek için ilkokul dönemindeki öğrenciler sözel problem çc̈zme ve sözel problemlerin dilsel boyutundaki karmaşıkla baş etme konusunda yeterince deneyim yaşamalıdır. Öğrencilerin bu konuda deneyim kazanmasında öğretmen ve ders kitabı olmak üzere iki etmenin önemli olduğu düşünülmektedir. Öğretmenler ve ders kitapları aracılığıyla öğrencilere özellikle işlemle tutarsız anahtar sözcükler içeren sözel problem türlerinin sunulması öğrencilerin bu konudaki performansını olumlu yönde etkileyebilir. Öğrencilerin özellikle işlemle tutarsız anahtar sözcükler içeren problemlerde düşük performans göstermesi öğretmenlerin bu tür örneklere derste daha az yer vermesinden ve problem çözmede anahtar sözcüklere vurgu yapmasından kaynaklanmış olabilir. Gelecek araştırmalarda öğrencilerin problem çözme performansını değerlendirmenin yanı sıra sınıf içi gözlemlerin gerçekleştirilmesi ve bu konuda öğretmenlerin sundukları problem türlerinin ve çözüm stratejilerinin incelenmesi oldukça önemlidir. Ayrıca ders kitaplarında TÇ ve ÇT türündeki problemlere ve tutarsız anahtar sözcüklerin kullanımına daha çok yer verilmesi hem öğretmenlerin bu konudaki farkındalığını arttırabilir, hem de öğrencilerin performansını olumlu yönde etkileyebilir.

Öğrencilerin problem çözme performansı üzerinde tutarlılık etkisinin varlığı farklı başarı gruplarından 20 öğrenciyle yapılan yarı yapılandırılmış görüşmeler sonucunda ortaya konulmuştur. Öğrencilere işlem seçimlerinin gerekçeleri sorulduğunda, büyük bir çoğunluğu işlemle tutarlı ve tutarsız anahtar sözcüklere vurgu yapmıştır. İşlemle tutarsız anahtar sözcüklerin yer aldığı problemler, genellikle düşük ve orta başarı grubundaki öğrencilerin hatalı işlem tercihinde bulunmasına neden olmuştur. Ancak düşük başarı grubundaki bazı öğrenciler her iki problem türünde de soruların yarısından fazlasına yanlış yanıt vermişlerdir. Bu durum bazı öğrencilerin sözel problem çözme performansı üzerinde tutarlılık etkisi dışında faktörlerin de etkili olabileceği ihtimalini akla getirmektedir. Araştırmacılar sözel problem çözme becerisinin işleyen bellek yapısıyla ilişkisine vurgu yapmakta olup dilsel ve aritmetik becerilerin işleyen bellek kapasitesi ile yakından ilişkili olduğu tespit edilmiştir (Daroczy ve diğerleri, 2015). Bu sebeple öğrencilerin sözel problem çözme performansı üzerindeki etkiler işleyen bellek kapasitesini de içeren farklı bileşenler bağlamında incelenmelidir.

Araştırmamız sonucunda Türkçe dersi akademik başarısı düşük öğrencilerin işlemle tutarsız anahtar sözcükler içeren problemlerde daha düşük performans sergilediği görülmüştür. Ancak öğrencilerin Türkçe dersi akademik başarıları karne notu ve öğretmen görüşlerine göre değerlendirilmiş olup okuduğunu anlama becerileri doğrudan ölçülmemiştir. Boonen ve diğerleri (2016) tarafından yapılan araştırmada, okuduğunu anlama becerisinin anlamsal olarak karmaşık problemlerdeki performansı geliştirmede yardımcı olabileceği ortaya konulmuştur. Dolayısıyla öğrencilerin okuduğunu anlama becerilerinin geliştirilmesine yönelik çalışmaların gerçekleştirilerek bu sürecin işlemle tutarsız anahtar sözcükler içeren problemlerdeki performanslarına etkisi incelenebilir. Yapılan araştırmalar ortaokul ve üniversite yıllarında bir grup öğrencinin sözel problemlerin anlamsal yapısına bağlı olarak zorlandıklarını ortaya koymaktadır (Hegarty ve diğerleri, 1995; Soylu, 2007; van der Schoot ve diğerleri, 2009).

Araştırma kapsamında öğrencilerin matematik ve Türkçe derslerine ait başarı durumları öğretmen görüşlerine göre belirlenmiştir. Öğretmenlerden değerlendirme yaparken öğrencilerin karne notlarını ve derse ilişkin akademik performansını göz önünde bulundurması istenmiştir. Öğretmenlerin sınıf öğretmeni olması ve en az iki yıldır öğrencileri tanıyor olması gibi etmenler yapılan değerlendirmelerin güvenirliğini arttırmaktadır. Ancak gelecek araştırmalarda öğrencilerin Türkçe ve matematik derslerine ilișkin başarıları, başarı testleri ile ölçülerek daha geçerli ve güvenilir sonuçlar elde edilebilir. Ayrıca bu derslerdeki akademik başarının önemsenmesinin iki sebebi bulunmaktadır. Türkçe ve matematik derslerine ait öğretim programlarında hem okuduğunu anlama hem de problem çözme becerisini desteklemeye yönelik kazanımlar ön plandadır. Dolayısıyla her iki dersteki akademik başarı, öğrencilerin problem çözme ve okuduğunu anlama becerilerini yansıtan değişkenler olarak kabul edilmiştir. Türkçe ve matematik derslerine ilişkin başarının yanı sıra öğrencilerin okuduğunu anlama ve problem çözme becerilerinin, bu 
becerilere yönelik ölçme araçları yardımıyla incelenmesi oldukça önemlidir.

Öğrencilerin problem çözümleri analiz edilirken doğru/yanlış kodlaması yapılmış olup rubrik aracılığıyla problem çözme aşamaları puanlanmamıştır. Bu durumun sebebi, öğrencilerin problem çözme performansının akademik başarı değişkeni ile ilişkilendirilmesidir. Doğru/yanlış şeklinde yapılan değerlendirme öğrencilerin performansı hakkında bilgi sağlamakla birlikte öğrencilerin problem çözme aşamalarını daha detaylı incelemek konusunda sınırlılık oluşturmaktadır. Bu sınırlılığı ortadan kaldırmak ve öğrencilerin problem çözme performansını daha iyi tanımlayabilmek amacıyla gelecek araştırmalarda, öğrencilerin problem çözme becerisini değerlendirmeye yönelik rubrik geliştirilmesi önerilmektedir. Öğrencilerle gerçekleştirilen yarı yapılandırılmış görüşmeler 15-45 dakika arasında sürmüş ve zaman zaman öğrencilerin okuduğunu anlama ya da dikkat düzeyindeki eksikliklerden dolayı hatalı cevaplar verdikleri görülmüştür. Ayrıca görüşme sürecinde araştırmacı tarafından yapılan müdahalelerin öğrencilerin performansını etkilediği ve dikkat düzeyindeki eksiklerden kaynaklı hataları fark etmelerini sağladığı görülmüştür. Bu sebeple bir grup öğrencinin performansındaki eksiklikleri doğrudan okuduğunu anlama ya da problem çözme becerisindeki yetersizlikle açıklamak mümkün olmayabilir. Öğrencilerin problem çözme performansındaki eksikliklerin daha iyi tanımlanabilmesi açısından rubrik kullanılmasının önemli olduğu düşünülmektedir. Ayrıca bu araştırma kapsamında kullanılan sözel problem türleri problemi anlama ve çözme noktasında daha temel düzeyde beceriler gerektirmektedir. Basit cümlelerle sunulan bu problem yapılarında anahtar sözcükler öğrencilerin dikkatini daha fazla çekmiş ve problem çözme sürecini ve

performansları etkilemiş olabilir. Bu konuda çalışmalar gerçekleştirecek araştırmacılara, işlemle tutarlı ve tutarsız anahtar sözcükler içeren problemleri daha karmaşık yapıda bağlamlar içeren problemler aracılığıyla sunmaları ve öğrencilerin performanslarını, problem çözme adımlarını yansıtan rubrikler aracılığıyla değerlendirmeleri önerilmektedir.

\section{Yazarların Beyanı}

Araştırmacılarn katkı oranı beyanı: Problem durumunun tespiti ve araştırma sorularının belirlenmesi iki yazarın katkısıyla gerçekleştirilmiştir. Birinci yazar veri toplama ve veri analizi aşamalarında görev almıştır. İkinci yazar veri analizi ve raporlaştırma aşamalarından sorumludur.

Çatışma beyanı: Makalenin yazarları bu çalışma ile ilgili taraf olabilecek herhangi bir kişi ya da finansal ilişkileri bulunmadığını dolayısıyla herhangi bir çıkar çatışmasııı olmadı̆̆ını beyan ederler.

Destek ve teşekkür: Bu araştırma TÜBİTAK tarafindan 2019/1 döneminde 2209-A Üniversite Öğrencileri Araştırma Projeleri Destekleme Programı kapsamında desteklenmiş olup Dr. Derya Can danışmanlığında Hicran Nurse Yıldız tarafından gerçekleştirilmiştir. TÜBïTAK'a sağlamış olduğu destekten dolayı teşekkürlerimizi sunariz.

\section{Kaynaklar}

Albayrak, M. ve Erkal, M. (2003). Başarıya giden yolda ifade ve beceri derslerinin (Türkçe-Matematik) birlikteliği. Millî Ĕgitim Dergisi, 158(1), 150-155.

Andersson, U. (2007). The contribution of working memory to children's mathematical word problem solving. Applied Cognitive Psychology, 21(9), 1201-1216. doi:10.1002/acp.1317.

Baki, A. (2006). Kuramdan uygulamaya matematik eğitimi. Trabzon: Derya Kitabevi.

Boonen, A. J. H., de Koning, B. B., Jolles, J. ve van der Schoot, M. (2016). Word problem solving in contemporary math education: A plea for reading comprehension skills training. Frontiers in Psychology, 7(191), 1-10.

Boonen, A. J. H., van der Schoot, M., Van Wesel, F., De Vries, M. H. ve Jolles, J. (2013). What underlies successful word problem solving? A path analysis in sixth grade students. Contemporary Educational Psychology, 38(3), 271-279.

Cohen, J. (1988). Statistical power analysis for the behavioral sciences (2. bs.). Hillsdale, NJ: Lawrance Erlbaum 
Associates.

Çelik, D. ve Taşkın, D. (2015). 5., 6. ve 7. Sınıf öğrencilerinin aritmetik sözel problemleri çözme sürecinin incelenmesi. İlköğretim Online, 14(4), 1439-1449.

Daroczy, G., Wolska, M., Meurers, W. D. ve Nuerk, H. C. (2015) Word problems: a review of linguistic and numerical factors contributing to their difficulty. Frontiers in Psychology, 6(348), 22-34.

De Corte, E., Verschaffel, L. ve Pauwels, A. (1990). Influence of the semantic structure of word problems on second graders' eye movements. Journal of Educational Psychology, 82(2), 359-365.

de Koning, B. B. ve van der Schoot, M. (2020). Can "you" make a difference? Investigating whether perspective-taking improves performance on inconsistent mathematical word problems. Applied Cognitive Psychology, 33(5), 911-917.

Fuchs, L. S., Fuchs, D., Compton, D. L., Hamlett, C. L. ve Wang, A. Y. (2015). Is word-problem solving a form of text comprehension? Scientific Studies of Reading, 19(3), 204-223.

Fuchs, L. S., Fuchs, D., Compton, D. L., Powell, S. R., Seethaler, P. M., Capizzi A. M. ve Fletcher, J. M. (2006). The cognitive correlates of third-grade skill in arithmetic, algorithmic computation, and arithmetic word problems. Journal of Educational Psychology, 98(1), 29-43. doi: 10.1037/0022-0663.98.1.29.

Hegarty, M., Mayer, R. E. ve Green, C. E. (1992). Comprehension of arithmetic word problems: evidence from students' eye fixations. Journal of Educational Psychology, 84(1), 76-84.

Hegarty, M., Mayer, R. E. ve Monk, C. A. (1995). Comprehension of arithmetic word problems: a comparison of successful and unsuccessful problem solvers. Journal of Educational Psychology, 87(1), 18-32.

İskenderoğlu, T., Akbaba-Altun, S. ve Olkun, S. (2004). İlköğretim 3., 4. ve 5. sinıf öğrencilerinin standart sözel problemlerde işlem seçimleri. Hacettepe Üniversitesi Ĕ̆itim Fakültesi Dergisi, 27(27), 126-134.

Karasar, N. (2017). Bilimsel araştırma yöntemi (32. bs.). Ankara: Nobel Yayın Dağıtım.

Kelley, T. L. (1939). The selection of upper and lower groups for the validation of test items. Journal of Educational Psychology, 30(1), 17-24.

Kintsch, W. ve Greeno, J. G. (1985). Understanding and solving word arithmetic problems. Psychological Review, 92(1), 109-129.

Kroll, D. L., ve Miller, T. (1993). Insights from research on mathematical problem solving in the middle grades. D. T. Owens (Ed.), Research ideas for the classroom: Middle grades mathematics (s. 58-77) içinde. Reston: NCTM.

Milli Eğitim Bakanlığı. (2018). Matematik dersi öğretim programı (İlkokul ve ortaokul 1, 2, 3, 4, 5, 6, 7 ve 8 . sinıflar). Ankara: Milli Eğitim.

Milli Eğitim Bakanlığı. (2019). Türkçe dersi öğretim programı (İlkokul ve ortaokul 1, 2, 3, 4, 5, 6, 7 ve 8 . sinıflar). Ankara: Milli Eğitim.

Olkun, S. ve Toluk-Uçar, Z. (2007). İlköğretimde etkinlik temelli matematik öğretimi (3. bs.). Ankara: Maya Akademi.

Pape, S. J. (2003). Compare word problems: Consistency hypothesis revisited. Contemporary Educational Psychology, 28(3), 396-421.

Soylu, Y. (2007). Öğrencilerin sözel problemleri çözerken sergiledikleri yaklaşımlar ve coğrafi bölgelere göre başarı oranlarının incelenmesi. Ondokuz Mayıs Üniversitesi, 24, 13-24.

Spencer, M., Fuchs, L. S. ve Fuchs, D. (2020). Language-related longitudinal predictors of arithmetic Word problem solving: A structural equation modeling approach. Contemporary Educational Psychology, 60(1), 116. 
Tertemiz, N. (1994). Illkokulda aritmetik problemleri çz̈zmede etkili görülen bazı faktörler (Yayımlanmamış doktora tezi). Hacettepe Üniversitesi, Ankara.

Thevenot, C., Devidal, M., Barrouillet, P. ve Fayol, M. (2007). Why does placing the question before an arithmetic word problem improve performance? A situation model account. The Quarterly Journal of Experimental Psychology, 60(1), 43-56. doi: 10.1080/17470210600587927.

Van de Walle, J. A. (1994). Elementary school mathematics teaching developmentally. New York, NY: Longman.

van der Schoot, M., Bakker Arkema, A. H., Horsley, T. M. ve van Lieshout, E. D. C. M. (2009). The consistency effect depends on markedness in less successful but not successful problem solvers: An eye movement study in primary school children. Contemporary Educational Psychology, 34(1), 58-66.

Verschaffel, L., De Corte, E. ve Pauwels, A. (1992). Solving compare problems: An eye movement test of Lewis and Mayer's consistency hypothesis. Journal of Educational Psychology, 84(1), 85-94.

Verschaffel, L., Greer, B. ve De Corte, E. (2000). Making sense of word problems. Lisse, The Netherlands: Swets \& Zeitlinger. 
İlkokul Öğrencilerinin Sözel Problem Çözme...

\section{Ek-1. Problem Türleri}

\section{İşlemle tutarlı anahtar sözcük içeren sözel problemler-TTÇÇ sözel problemleri}

Toplama anahtar sözcüğü içeren ve toplama işlemi gerektiren problemler-TT

1)Ayşe annesiyle hayvanat bahçesine gittiğinde 8 kırmızı papağan ile 7 sarı papağan görmüştür. Ayşe toplam kaç papağan görmüştür?

4)Bir akvaryumda 12 tane balık vardır. Akvaryuma 7 balık daha ilave edilirse akvaryumda kaç balık olur?

8) Berk'in 9 tane hikâye kitabı, 8 tane de masal kitabı varsa toplam kaç kitabı vardır?

15)Ali arkadaşlarıyla bilyelerle oynamaya başladığında 12 tane bilyesi vardı. Ali'nin bilyeleri 7 tane artınca kaç bilyesi olur?

19) Görkem'in 11 tane kırmızı kalemi ve 9 tane kurşun kalemi vardır. Görkem'in toplam kaç tane kalemi vardır?

Çıkarma anahtar sözcüğü içeren ve çıkarma işlemi gerektiren problemler-ÇÇ

2)Ahmet'in 16 tane oyun kartı vardır. Ahmet oyun kartlarının 4 tanesini arkadaşlarına verdiğinde Ahmet'in kaç tane oyun kartı kalmıştır?

11)Mustafa'nın 17 tane pinpon topu vardır. Arkadaşlarıyla oyun oynarken 6 tanesi eksildiğinde kaç pinpon topu kalır?

14)Anneleri iki kardeşe eve gelirken 9 tane boncuk getirir. Kardeşler sabah kalktıklarında boncukların 7 tanesinin eksilmiş olduğunu görürler. Geriye kaç tane boncuk kalmıştır?

18) 18 arkadaş okulun bahçesinde oyun oynamaktadır. Oyundan 5 kişi çıktığında oyunda kaç kişi kalır?

\section{İşleme tutarsız anahtar sözcük içeren sözel problemler-TÇÇT sözel problemleri}

Toplama anahtar sözcüğü içeren ve çıkarma işlemi gerektiren problemler -TÇ

5)Yağmur 'un arkadaşları için yaptığı kekler toplam 17 tanedir. Yapılan keklerin 4 tanesi artmıştır. Kaç tane kek yenmiştir?

7)Ayça'nın doğum gününe davet ettiği 18 arkadaşından toplam 3 tanesi gelmemiştir. Ayça'nın doğum gününe kaç arkadaşı gelmiştir?

9)Gizem'in 13 kırmızı tokası ile 5 mavi tokası vardır. Gizem'in kırmızı tokaları mavi tokalarından kaç tane fazladır?

13)Rıza Amca'nın 19 koyunu ve Hüseyin Amca'nın 8 koyunu vardır. Rıza Amca'nın koyunları kaç tane fazladir?

17)Bir vazonun içinde güller vardır. Vazoya 8 gül daha katılınca 20 gül olmuştur. Başlangıçta vazoda kaç gül vardir?

Çıkarma anahtar sözcüğü içeren ve toplama işlemi gerektiren problemler-ÇT

3)Teneffüs zili çaldığında sınıftaki öğrencilerin 16 tanesi bahçeye çıkmış 4 tanesi sınıfta kalmıştır. Bu sınıfta kaç öğrenci vardır?

6)Funda'nın tokalarının 8 tanesi eksilince 7 tane tokası kalıyor. Funda'nın kaç tokası vardır?

12)Saklambaç oynayan çocukların 5 tanesi çıktığında 13 çocuk kalmıştır. Oyuna başlarken kaç çocuk vardır?

16)Bir tabaktaki 7 kurabiye eksildiğinde 9 kurabiye kalıyor. Tabakta kaç kurabiye vardır? 


\section{EXTENDED ABSTRACT}

\section{Introduction}

One of the situations that creates complexity in word problems is whether or not the keywords in the problems are consistent with the mathematical operations required for the solution of such problems (Hegarty, Mayer ve Green, 1992; Hegarty, Mayer ve Monk, 1995; Pape, 2003). In a word problem containing consistent keywords, the relevant expression (for example, "more") is associated with the arithmetic operation (addition). However, when the word problem contains keywords that are inconsistent with the operation needed, these words (for example, "less") are not related to arithmetic operations (addition). There are studies dealing with the effects of keywords on the problem-solving performance of individuals from different age groups (Boonen, van der Schoot, Van Wesel, De Vries and Jolles, 2013; Hegarty, Mayer and Green, 1992; van der Schoot, Bakker Arkema, Horsley and van Lieshout, 2009). In this study, the aim is to examine the problem-solving performance of the students with regard to word problems that contain keywords that are consistent and inconsistent with the necessary mathematical operations, and to investigate the role of such expressions in the mathematical operation preferences of the students. In addition, the relationship between the students' academic achievement in the Turkish language and in mathematics courses and their problem-solving performance, is examined. The aim is also to reveal how the performance of the students with regard to problems which are stated in a way that is consistent and inconsistent with the operation needed to solve the problem varies, and is based on the academic achievement levels of the students. In relation to these aims, the study attempts to answer the following research question: "How do primary school students perform in the case of word problems that contain consistent and inconsistent keywords?"

\section{Method}

In an attempt to describe the existing situation, the survey method, which is a form of descriptive research, is used. The study consists of qualitative and quantitative parts. First the latter was carried out. In this part the students' performance with regard to problems that are either consistent or inconsistent with the operations needs is examined. In the qualitative part of the study the choice of the mathematical operation for both problem types, the reasons for the choice of operation, and the role of the keywords in this process, were examined in terms of three groups of students, namely high, medium and lower achievement groups with regard to courses in Turkish language and mathematics. The participants in the quantitative part of the study are 100 students in the third and fourth grades of primary schools. They were selected through convenience sampling. In the qualitative phase of the research, semi-structured interviews were conducted and the participants were selected through maximum variation sampling. The interviewees are twenty students grouped into three categories based on their academic achievement in Turkish language and mathematics courses. The data of the study were collected using word problems which were used in the study by İskenderoğlu, Akbaba-Altun and Olkun (2004). The verbal problems used in the study are in two categories - those with keywords that are consistent with the mathematical operation and those that are inconsistent. Whether or not student performance differs significantly based on their academic achievement levels in Turkish language and mathematics was tested with the use of one-factor variance analysis. Descriptive analysis was used to analyze the data obtained in the qualitative phase of the research. More specifically, this analysis included the rate of correct answers, the mathematical operations used by the participants, the reasons for choosing a particular operation, and their views about the effects of the keywords in the process.

\section{Results}

It is found that the student performance is much higher in the case of word problems with lexicallyconsistent keywords, compared with those with lexically-inconsistent keywords. The results of the analysis show that the problem-solving performance of the students varies in terms of their achievement in Turkish language and mathematics courses. The difference between students in the lower achievement groups compared with the other students becomes much clearer in problems with inconsistent keywords. The 
consistence effect on the students' problem-solving performance were analysed through clinical interviews with twenty students from distinct achievement groups. When the participants were asked to justify their choices over the operations, the majority stated that they considered the keywords which were consistent and inconsistent with the operations. Problems with keywords that are inconsistent with the operations generally caused students in the lower and medium achievement group to choose incorrect operations to solve the problems. However, some students in the lower achievement group answered more than half of the questions incorrectly in both types of problem. This situation can be interpreted as the effects of factors other than the consistency effect on the lower achieving students' word problem solving performance.

\section{Conclusion}

The findings of the study indicate that students with low academic achievement in Turkish language performed lower with regard to the problems containing keywords that were inconsistent with the process. However, the academic achievement of the students in terms of Turkish language was evaluated according to their grades and teacher opinions. Their reading comprehension skills were not directly measured in the study. However, Boonen et al. (2016) suggest that reading comprehension skills may improve student performance in the case of problems which are semantically complex. Therefore, studies could be carried out to improve students' reading comprehension skills. The effects of such activities on their problem solving performance may be analysed in relation to problems involving contradictory concepts. Research suggests that some secondary and undergraduate students have difficulty in comprehending word problems due to their semantic patterns (Hegarty et al., 1995; Soylu, 2007; van der Schoot et al., 2009). Developing students' reading comprehension skills and teaching them how to deal with the semantic-linguistic features of word problems, especially in the primary school period, may positively support their performance when they are older. 